Supporting Information:

Stereoselectivity and Regioselectivity in Nucleophilic Ring Opening and Unpredicted Dimerization and Ring Transformation in Derivatives of 3-phenylisoxazolo[2,3-a]pyrimidine and. Syntheses of Derivatives of Pyrimidinylmethylamine, Pyrimidinylmethylamino Acid Amides and a-Amino-2pyrimidinylacetamides ${ }^{1}$

Gury Zvilichovsky* and Isra Gbara-Haj-Yahia

Content:

$\begin{array}{ll}\text { General experimental data } & \text { S2 }\end{array}$

$\begin{array}{ll}\text { Preparation of amino acid amides } & \text { S3 }\end{array}$

High esolution MS of unidentified

red product obtained togtherwith product 30

Determination of isomeric ratios in reaction

mixtures of amino acid amides with derivatives

of 3-phenylisoxazolo[2,3-a]pyrimidine by1H NMR: S5

High resolution MS of $\mathbf{3 a} \quad$ S6

High resolution MS of $\mathbf{3 b} \quad$ S6

$\begin{array}{ll}\text { High resolution MS of } \mathbf{6 a} & \text { S7 }\end{array}$

$\begin{array}{ll}\text { High resolution MS of } \mathbf{6 b} & \text { S7 }\end{array}$

$\begin{array}{ll}\text { High resolution MS of } \mathbf{7 a} & \text { S8 }\end{array}$

$\begin{array}{ll}\text { High resolution MS of } \mathbf{7 b} & \text { S8 }\end{array}$

High resolution MS of $8 \mathbf{a} \quad$ S9

High resolution MS of $\mathbf{8 b} \quad$ S9

$\begin{array}{ll}\text { High resolution MS of 9a } & \text { S10 }\end{array}$

$\begin{array}{ll}\text { High resolution MS of } \mathbf{9 b} & \text { S10 }\end{array}$

$\begin{array}{ll}\text { High resolution MS of } \mathbf{1 0 a} & \text { S11 }\end{array}$

$\begin{array}{ll}\text { High resolution MS of 11a } & \text { S11 }\end{array}$

$\begin{array}{ll}\text { High resolution MS of } \mathbf{1 1 b} & \mathrm{S} 12\end{array}$ 
${ }^{1} \mathrm{HNMR},{ }^{13} \mathrm{CNMR}$ and high resolution MS of $\mathbf{3 0} \quad \mathrm{S} 16$

$\begin{array}{ll}{ }^{1} \text { HNMR of } 32 & \text { S16 }\end{array}$

$\begin{array}{ll}{ }^{1} \mathrm{HNMR} \text { and high resolution MS of } \mathbf{3 7} & \mathrm{S} 17\end{array}$

$\begin{array}{ll}{ }^{1} \mathrm{HNMR} \text { and high resolution MS of } 38 & \text { S17 }\end{array}$

Pictures of models made to determine the spatial influence on the chemical shifts of the methyl groups in 37-40 S19

$\begin{array}{ll}{ }^{1} \mathrm{HNMR} \text { of } 39 & \text { S20 }\end{array}$

$\begin{array}{ll}{ }^{1} \text { HNMR of } 40 & \text { S20 }\end{array}$

${ }^{1}$ HNMR of $\mathbf{4 1 + 4 2} \quad$ S21

${ }^{1}$ HNMR and high resolution MS of $\mathbf{4 3} \quad$ S21

${ }^{1}$ HNMR and high resolution MS of 44

$\begin{array}{ll}\text { Crystalographic procedure and data for } 30 & \text { S22 }\end{array}$

${ }^{1}$ HNMR of 45c $\quad$ S23

X-ray data and OTREP for 45c S24

$\begin{array}{ll}\text { X-ray data and ORTEP for } 34 & \text { S28 }\end{array}$

\section{General experimental data}

NMR spectra were taken with Bruker AMK-300 $(300 \mathrm{MHz})$ or $400 \mathrm{MHz}$. Optical rotation was measured with Perkin Elmer 141 polarimeter. Column separation with Silica Gel 60 (230-400 mesh), low-pressure elution. Petroleum ether $40-60^{\circ}$ was used for elution. TLC was carried out with Silica Gel 
60-F 254 , examined under UV light. Isotopic molecular weight ere calculated with: "Molecular Weight Calculator for Windows" Version 6.22.

Preparation of amino acid amides: These amides were prepared by known methods ${ }^{1,2}$ via the formation of $p$-nitrophenyl esters of $\mathrm{N}$-carbobenzoxy amino acids. The Latter intermediates were brought to reaction with amines in acetonitrile, in the presence of 1-hydroxybenztriazole $(0.8$ mole/1mole). The carbobenzoxy group was removed by hydrogenation on $10 \% \mathrm{Pd} / \mathrm{C}$ in methanol on icewater bath for $2 \mathrm{~h}$. Products were crystallized from ethyl acetate- petroleum ether. Data for Lcarbobenzoxy-N-cyclohexylalnaninamide: mp $164{ }^{\circ} \mathrm{C} ;{ }^{1} \mathrm{H}$ NMR $\left(\mathrm{CDCl}_{3}\right) \delta: 7.35\left(\mathrm{~s}, 5 \mathrm{H}, \mathrm{C}_{6} \underline{\boldsymbol{H}_{5}} \mathrm{CH}_{2} \mathrm{O}\right)$, 6.13 (bs, 1H-NH), 5.54 (d, J=6.90, 1H-NH), 5.10 (s, 2H, $\left.\mathrm{C}_{6} \mathrm{H}_{5} \underline{\mathrm{C}}_{2} \mathrm{O}\right), 4.20(\mathrm{~m}, 1 \mathrm{H}, \alpha-\mathrm{CH}), 3.20(\mathrm{~m}, 1 \mathrm{H}$, CHA), 1.86-1.08 (m, 10H, CHA), 1.38 [d, J=6.00, 3H, $\mathrm{CH}\left(\mathrm{CH}_{3}\right]$. Anal. Calcd for $\mathrm{C}_{17} \mathrm{H}_{24} \mathrm{~N}_{2} \mathrm{O}_{3}: \mathrm{C}_{\text {, }}$ 67.08.00; H, 7.95; N, 9.20. Found: C, 66.92; H, 7.95; N,9.20. Data for N-cyclohexylalnaninamide: mp

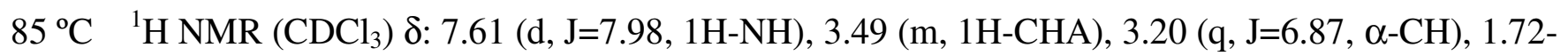
1.13 (m, 10H, CHA), 1.09 [d, J=6.84, 3H, $\mathrm{CH}\left(\mathrm{CH}_{3}\right]$. Anal. Calcd for $\mathrm{C}_{9} \mathrm{H}_{18} \mathrm{~N}_{2} \mathrm{O}: 0.4 \mathrm{HOH}$ : C, 61.02.00; $\mathrm{H}, 10.62 ; \mathrm{N}, 15.82$. Found: $\mathrm{C}, 61.03 ; \mathrm{H}, 10.43 ; \mathrm{N}, 15.67$. Data for L-carbobenzoxy-Ncyclohexylvalinamide: $\mathrm{mp} 208{ }^{\circ} \mathrm{C} .{ }^{1} \mathrm{H}$ NMR $\left(\mathrm{CDCl}_{3}\right) \delta: 7.28\left(\mathrm{~s}, 5 \mathrm{H}, \mathrm{C}_{6} \underline{\boldsymbol{H}}_{5} \mathrm{CH}_{2} \mathrm{O}\right), 5.73(\mathrm{~d}, \mathrm{~J}=8.40,1 \mathrm{H}-$ $\mathrm{NH}), 5.40$ (d, J=6.60, 1H-NH), $5.10\left(\mathrm{~s}, 2 \mathrm{H}, \mathrm{C}_{6} \mathrm{H}_{5} \underline{\mathrm{C}}_{2} \mathrm{O}\right), 3.85$ (dd, $\left.\mathrm{J}_{1}=8.40, \mathrm{~J}_{2}=6.90,1 \mathrm{H}, \alpha-\mathrm{CH}\right), 3.73$ (m, 1H, CHA), $2.07\left[\mathrm{~m}, 1 \mathrm{H}, \mathbf{C} \underline{\boldsymbol{H}}\left(\mathrm{CH}_{3}\right)_{2}\right]$ 1.86-1.08 (m, 10H, CHA), 0.92 [dd, J $=9.84, \mathrm{~J}_{2}=6.93,6 \mathrm{H}$, $\left.\mathrm{CH}\left(\mathrm{CH}_{3}\right)_{2}\right]$. Anal. Calcd for $\mathrm{C}_{19} \mathrm{H}_{28} \mathrm{~N}_{2} \mathrm{O}_{3}: \mathrm{C}, 68.65 . \mathrm{H}, 8.49 ; \mathrm{N}, 8.43$. Found: C, 68.50; H, 8.31; N, 8.22. Data for L- N-cyclohexylvalinamide: $\mathrm{mp} 89{ }^{\circ} \mathrm{C} .{ }^{1} \mathrm{H}$ NMR $\left(\mathrm{CDCl}_{3}\right) \delta: 7.62(\mathrm{~d}, \mathrm{~J}=7.86,1 \mathrm{H}-\mathrm{NH}), 3.53(\mathrm{~m}$, 1H-CHA), 2.86(d, J=5.34, $\alpha-\mathrm{CH}), 1.81-1.77$ [m, 1H, $\left.\underline{\mathrm{H}}\left(\mathrm{CH}_{3}\right)_{2}\right]$ 1.72-1.09 (m, 10H-CHA), 0.82 [dd, $\mathrm{J}_{1}=22.23, \mathrm{~J}_{2}=6.83,6 \mathrm{H}, \mathrm{CH}\left(\mathrm{C}_{\underline{3}} \underline{2}_{2}\right]$. Anal. Calcd for $\mathrm{C}_{11} \mathrm{H}_{22} \mathrm{~N}_{2} \mathrm{O}: \mathrm{C}, 66.62 . \mathrm{H}, 8.11 ; \mathrm{N}, 14.13$. Found: C, 66. 22; H, 11.05; N, 13.97. Data for L-carbobenzoxy-N-cyclohexylphenylalaninamide: $\mathrm{mp} 161{ }^{\circ} \mathrm{C} .{ }^{1} \mathrm{H}$ $\operatorname{NMR}\left(\mathrm{CDCl}_{3}\right) \delta: 7.38\left(\mathrm{~s}, 5 \mathrm{H}, \mathrm{C}_{6} \underline{\boldsymbol{H}_{5}} \mathrm{CH}_{2} \mathrm{O}\right), 7.30-7.19(\mathrm{~m}, 5 \mathrm{H}, \mathrm{Ph}), 5.46$ (br s, $\left.1 \mathrm{H}-\mathrm{NH}\right), 5.37$ (d, J=7.53, 1H-NH), 5.10 (s, 2H, $\left.\mathrm{C}_{6} \mathrm{H}_{5} \mathrm{C}_{\underline{2}} \mathrm{O}\right), 4.28$ (dt, $\left.\mathrm{J}_{1}=14.04, \mathrm{~J}_{2}=7.02,1 \mathrm{H}, \alpha-\mathrm{CH}\right), 3.70-3.61$ (m, 1H-CHA), 3.22 
(dd, $\left.\mathrm{J}_{1}=13.37, \mathrm{~J}_{2}=7.05,2 \mathrm{H}, \mathrm{C}_{2} \mathrm{C}_{6} \mathrm{H}_{5}\right), 1.79-0.83$ (m, 10H-CHA). Anal. Calcd for $\mathrm{C}_{23} \mathrm{H}_{28} \mathrm{~N}_{2} \mathrm{O}_{3}: \mathrm{C}, 72.60$.

H, 7.42; N, 7.36. Found: C, 72.44; H, 7.38; N, 7.16. Data for L- N-cyclohexylphenylalaninamide: mp 96 oC. ${ }^{1} \mathrm{H}$ NMR $\left(\mathrm{CDCl}_{3}\right)$ 8: 7.30-7.19 (m, 5H, Ph), $7.12(\mathrm{~d}, 1 \mathrm{H}-\mathrm{NH}), 3.74$ (m, 1H-CHA), 3.56 (dd, $\mathrm{J}_{1}=9.05$, $\left.\mathrm{J}_{2}=4.36, \alpha-\mathrm{CH}\right), 3.22\left(\mathrm{dd}, \mathrm{J}_{1}=13.69, \mathrm{~J}_{2}=4.28,1 \mathrm{H}, \underline{C}_{2} \mathrm{C}_{6} \mathrm{H}_{5}\right), 2.69\left(\mathrm{dd}, \mathrm{J}_{1}=13.67, \mathrm{~J}_{2}=4.62,1 \mathrm{H}, \underline{\mathrm{C}}_{2} \mathrm{C}_{6} \mathrm{H}_{5}\right)$,

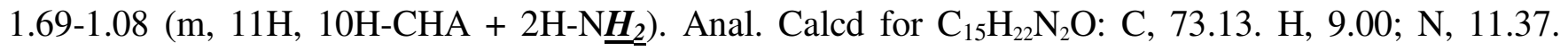

Found: C, 73.20; H, 8.77; N, 10.91. Data for L-carbobenzoxy-N-cyclohexylprolinamide: mp $149{ }^{\circ} \mathrm{C} .{ }^{1} \mathrm{H}$ NOR $\left(\mathrm{Cycl}_{\mathrm{e}}\right) \delta: 7.34$ (s, 5H, $\mathrm{C}_{6} \underline{\boldsymbol{H}_{5}} \mathrm{CH}_{2} \mathrm{O}$ ), 6.59 (br s, 1H-NH), 5.37 (br s, 5.73, 1H-NH), 5.17 (s, 2H, $\left.\mathrm{C}_{6} \mathrm{H}_{5} \mathrm{C}_{2} \underline{\boldsymbol{H}_{2}} \mathrm{O}\right), 4.28$ (m, 1H, $\left.\alpha-\mathrm{CH}\right), 3.68$ (m, 1H-CHA), 3.51 (m, 2H, Pro), 2.35-1.17 (m, 14H, 10H-CHA + 4H-Pro). Anal. Calcd for $\mathrm{C}_{19} \mathrm{H}_{26} \mathrm{~N}_{2} \mathrm{O}_{3}: \mathrm{C}, 69.06 . \mathrm{H}, 7.93 ; \mathrm{N}$, 8.48. Found: C, 69.34; H, 8.02; N, 8.47. Data for L-N-cyclohexylprolinamide: oil. Anal. Calcd for $\mathrm{C}_{11} \mathrm{H}_{20} \mathrm{~N}_{2} \mathrm{O} .0 .4 \mathrm{HOH}$ : C, 65.02. H, 10.24; N, 13.79. Found: C, 65.01; H, 9.99; N, 12.55 .

(1) Bodanszky, M.; Du Vigneaud, V. J. Am. Chem Soc., 1959, 81, 5688

Bodanszky, M.; Du Vigneaud, V. Biochem. Prep., 1962, 9, 110; M.Bodanszky, Denning, G.S.; Du Vigneaud, V. Biochem. Prep., 1963, 10, 122;

(2) Konig, W.; Geiger, R. Chem. Ber., 1970, 103, 788.

High esolution MS of unidentified red product obtained togtherwitproduct 30 


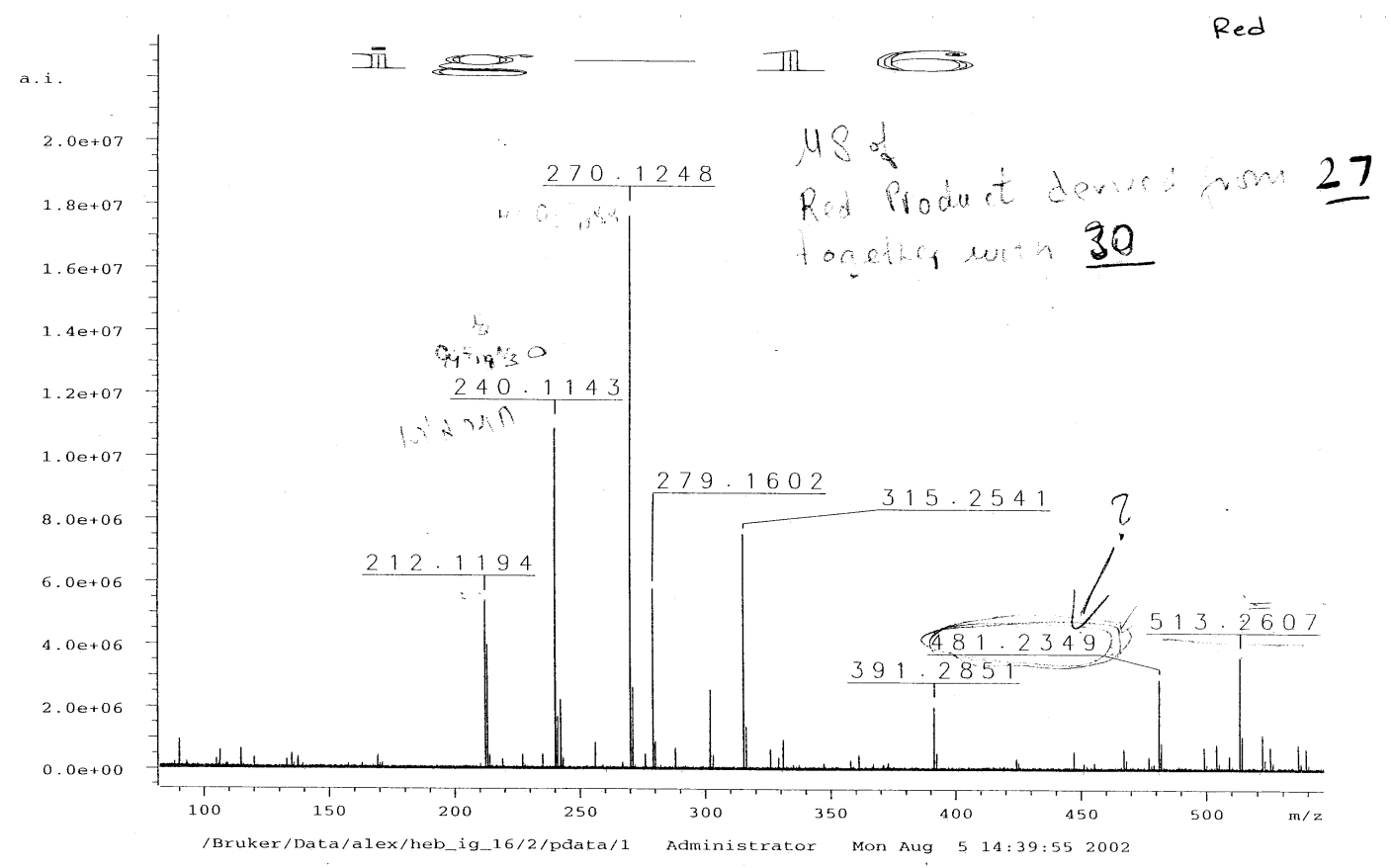

Determination of isomeric ratios in reaction mixtures of amino acid amides with derivatives of 3phenylisoxazolo[2,3-a]pyrimidine by ${ }^{1} \mathrm{H}$ NMR: 

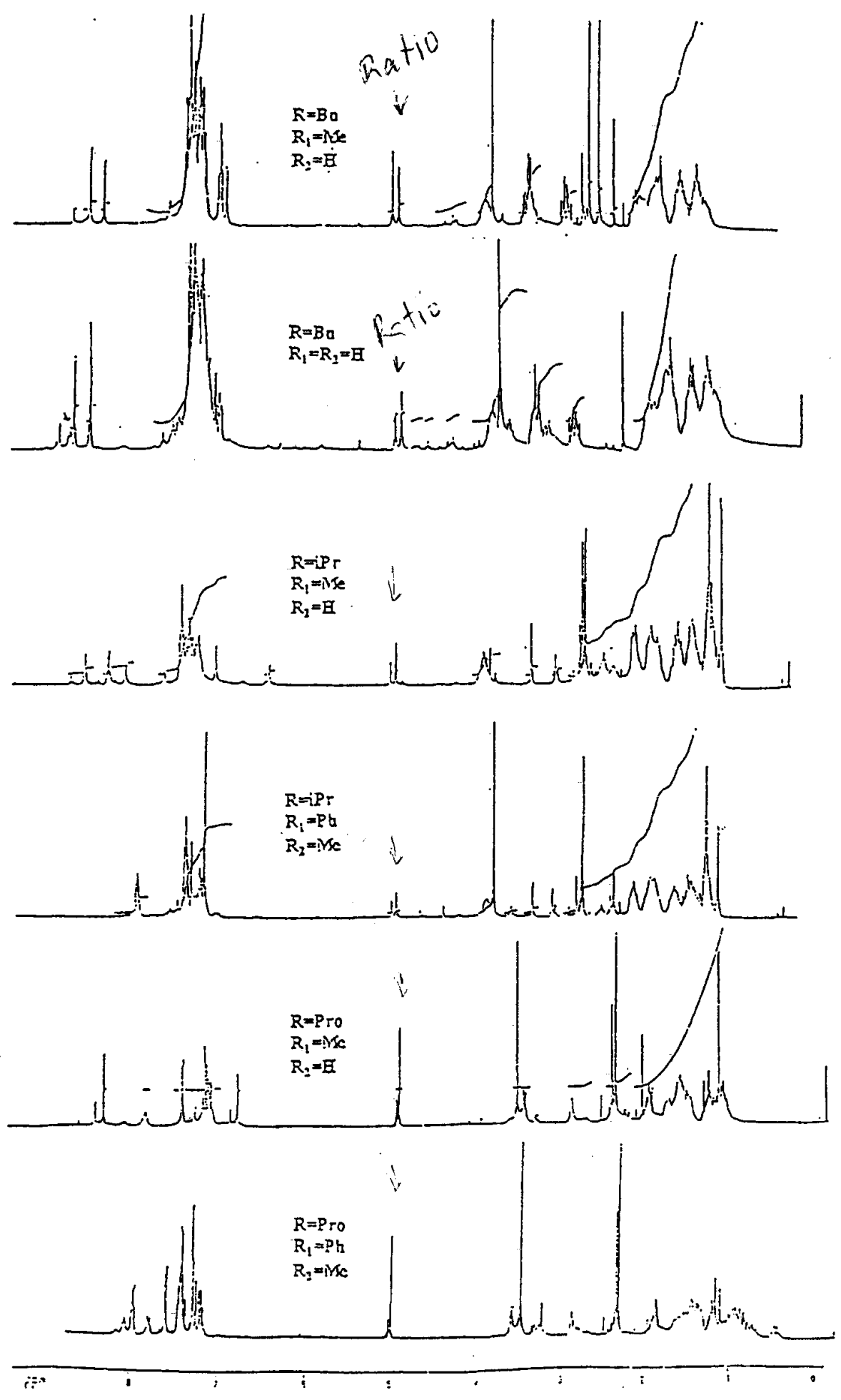


\section{High resolution MS}
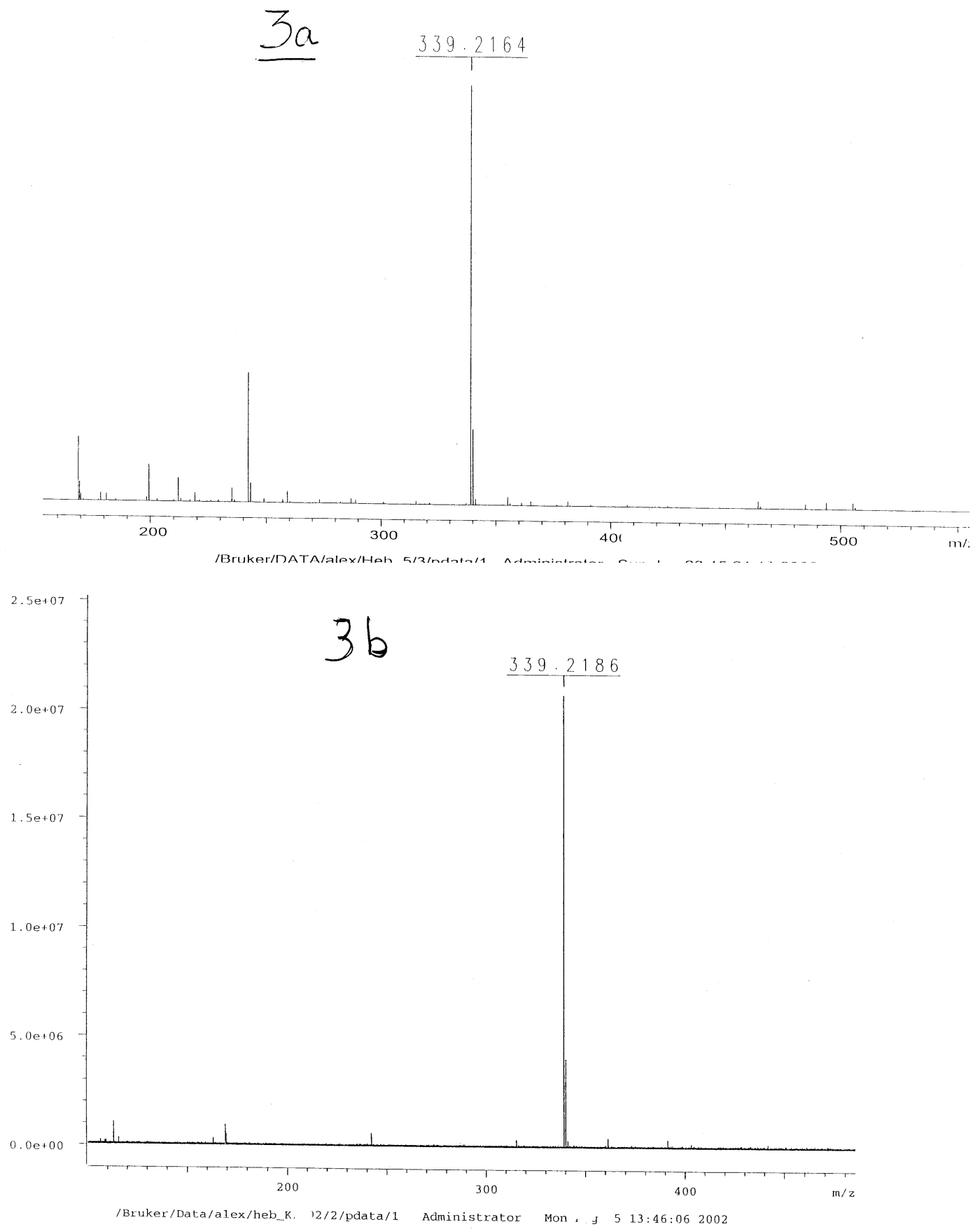

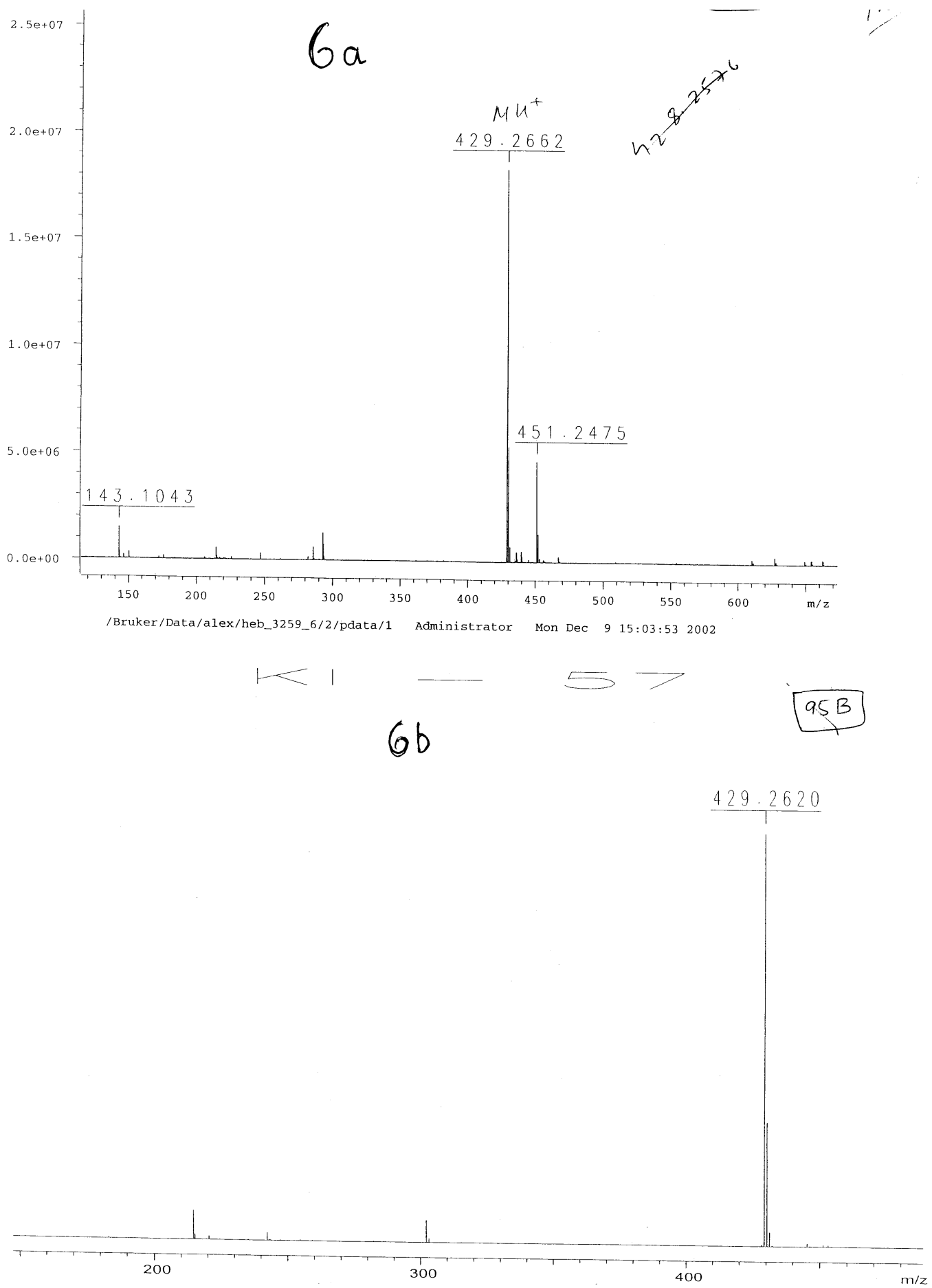

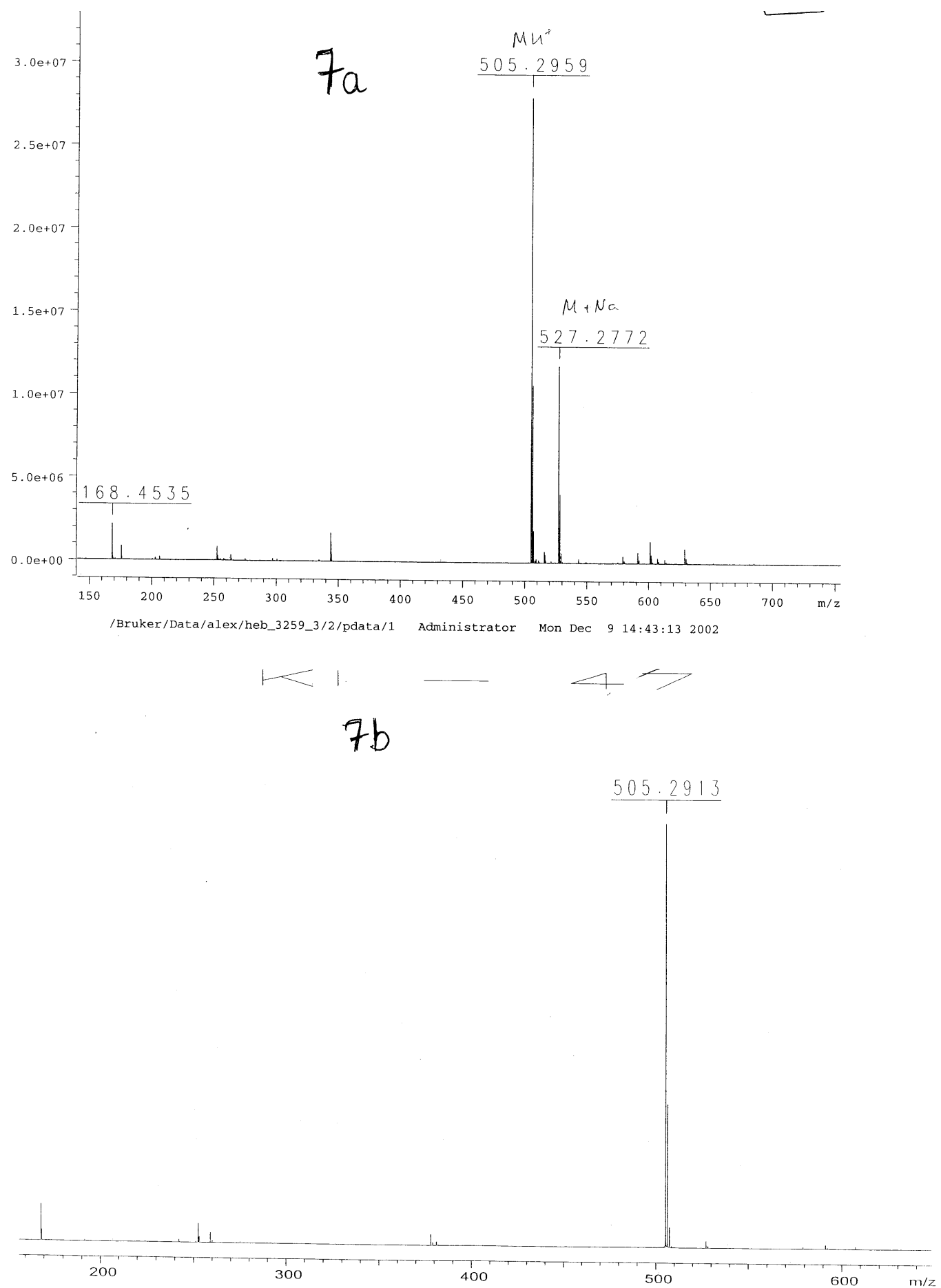

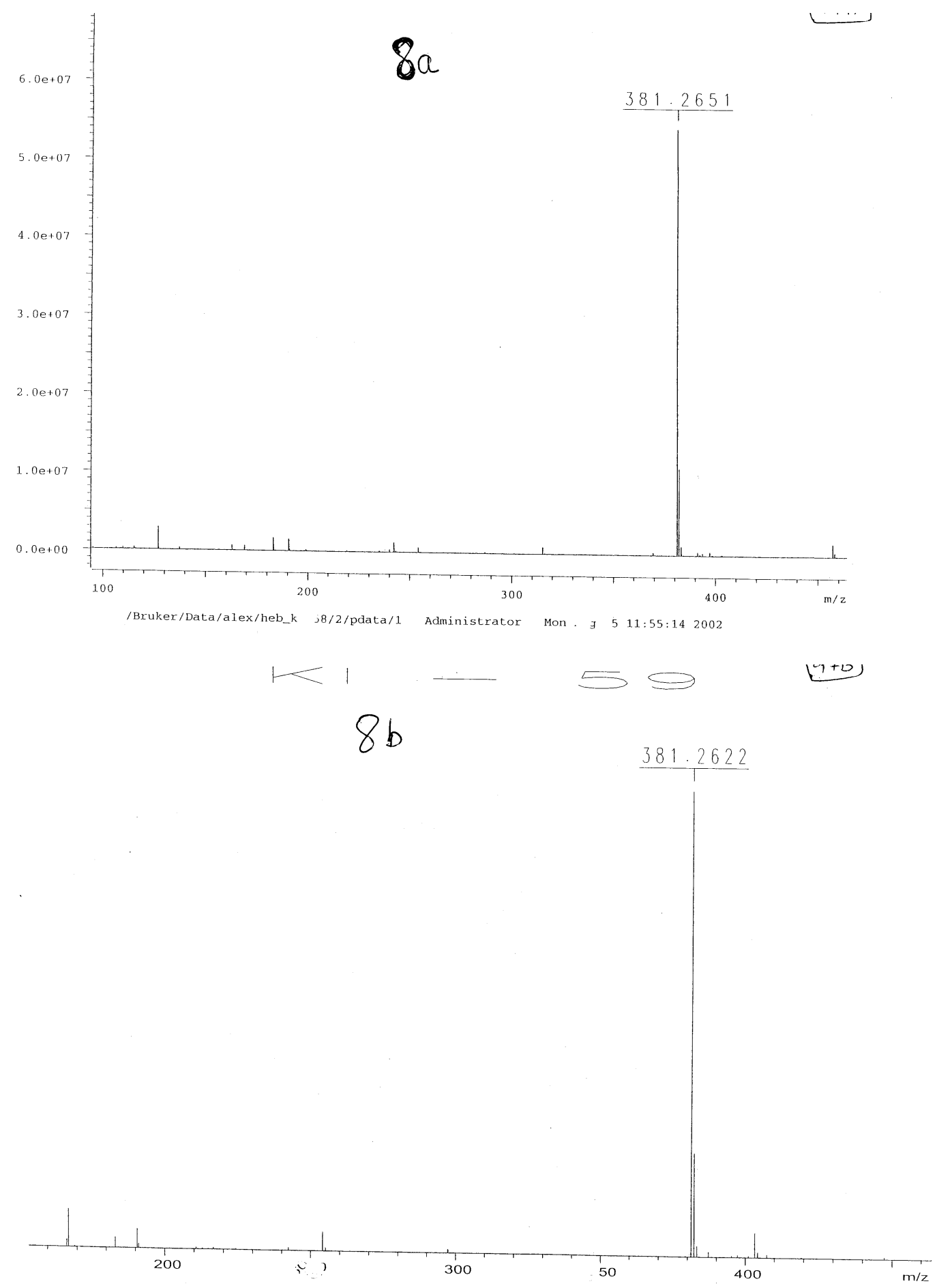

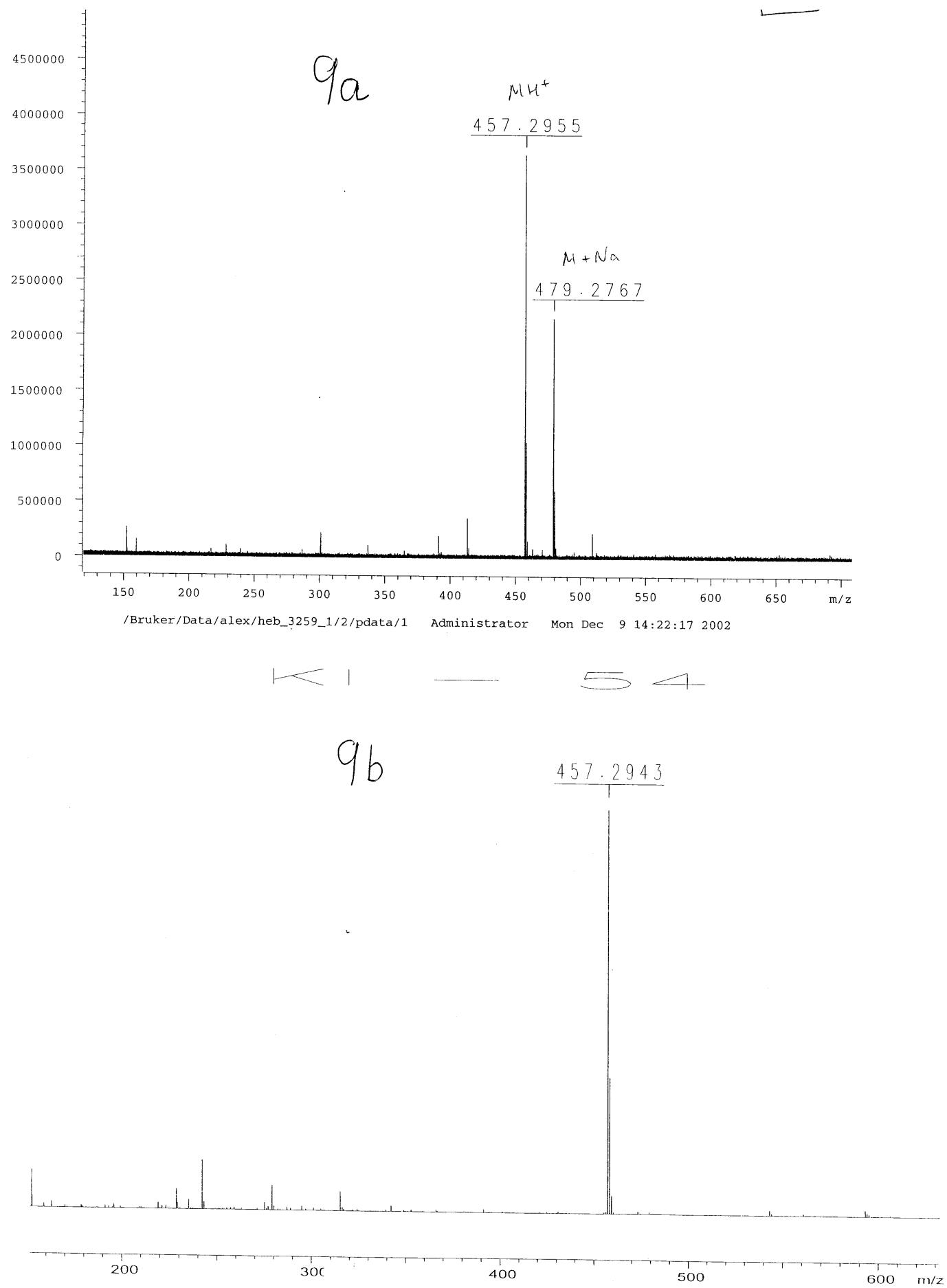

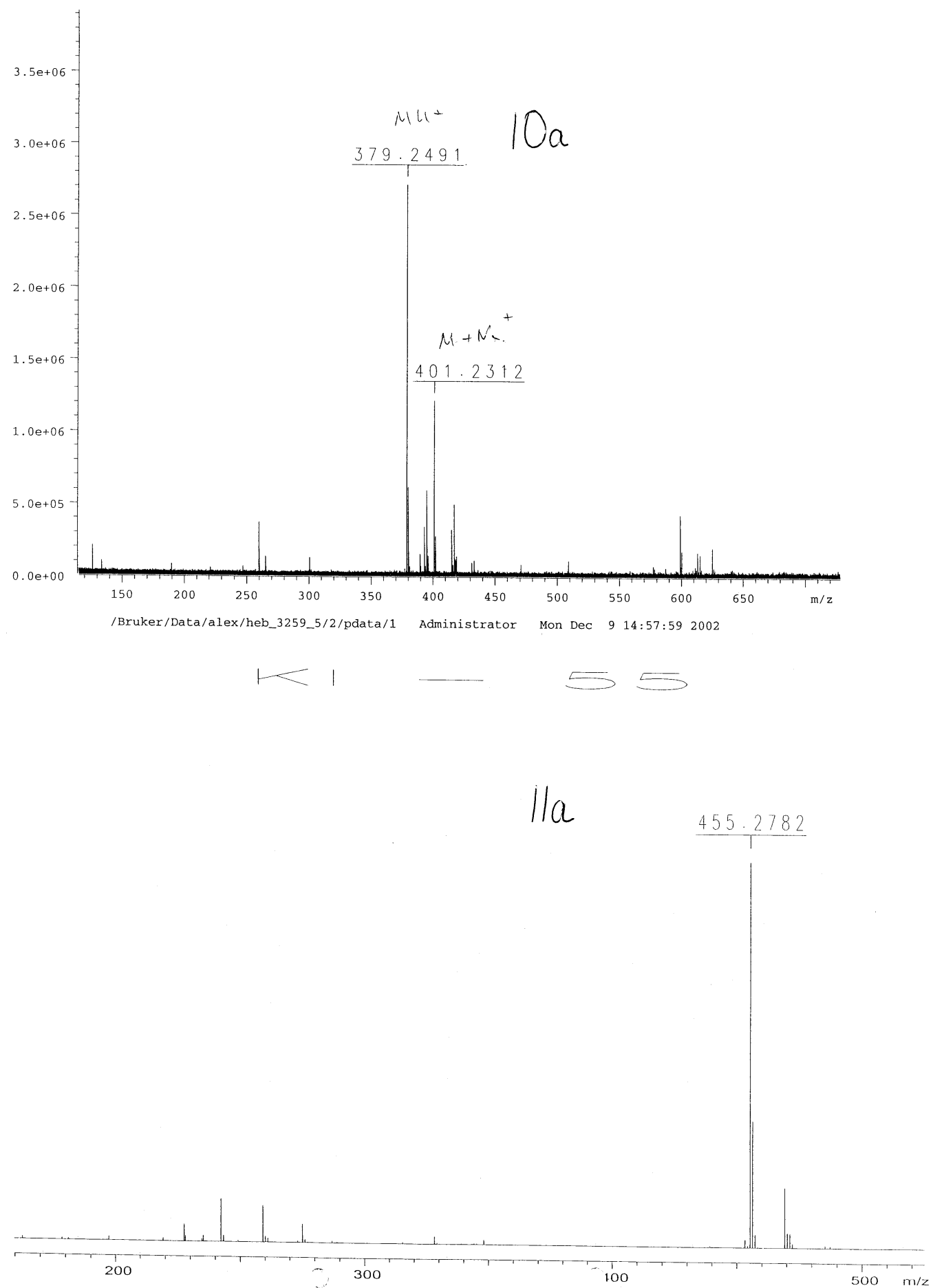

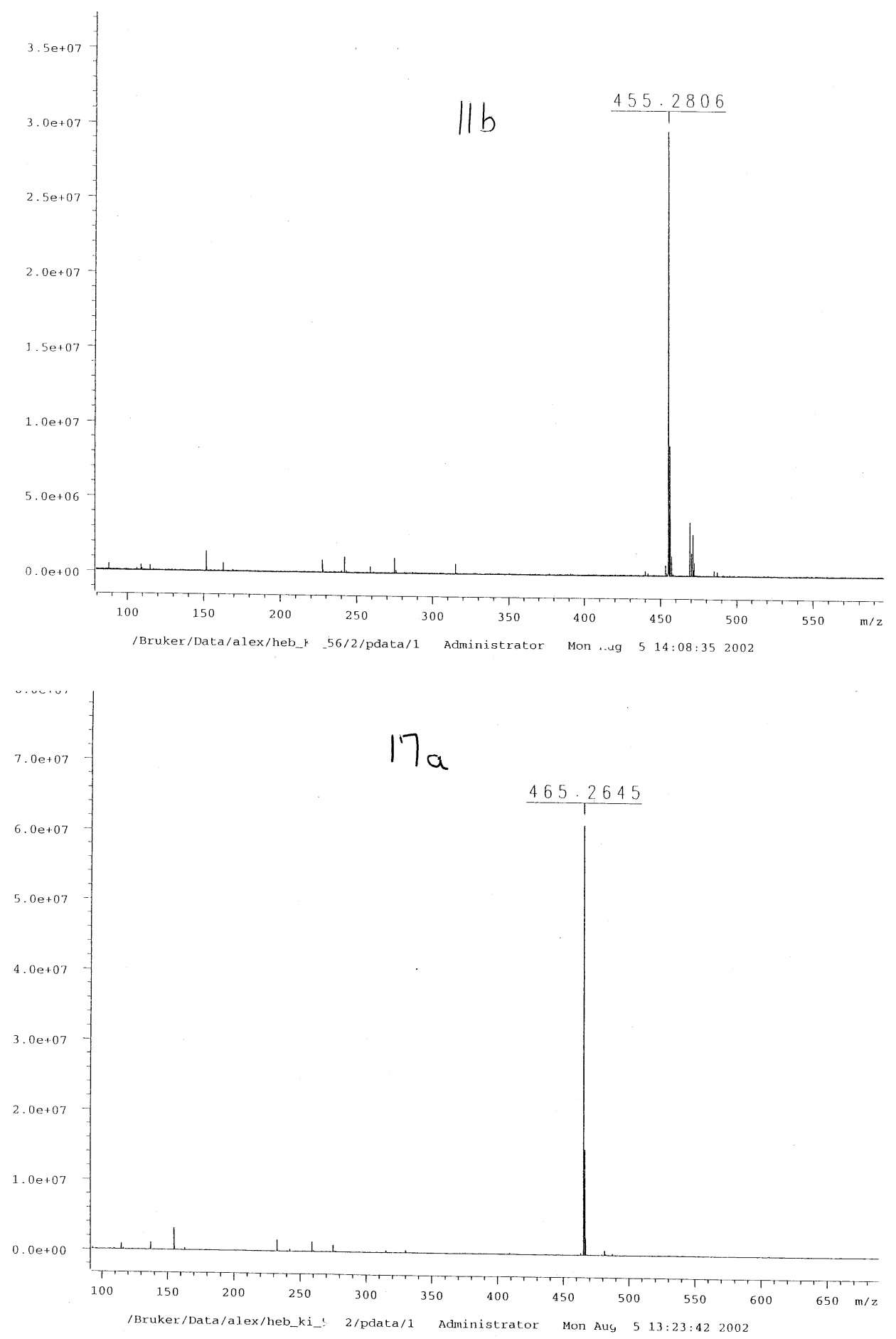
$1 \longrightarrow$

18
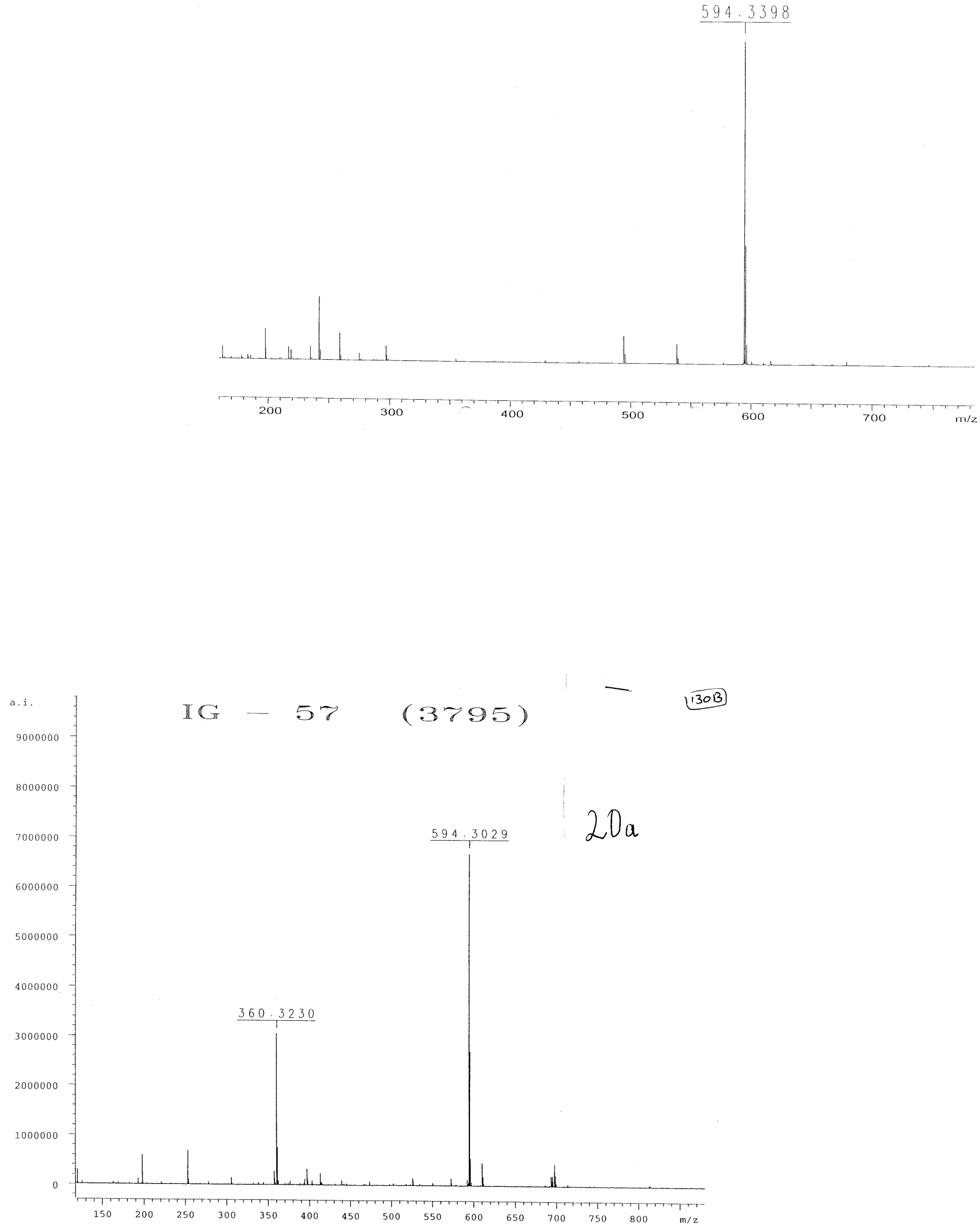

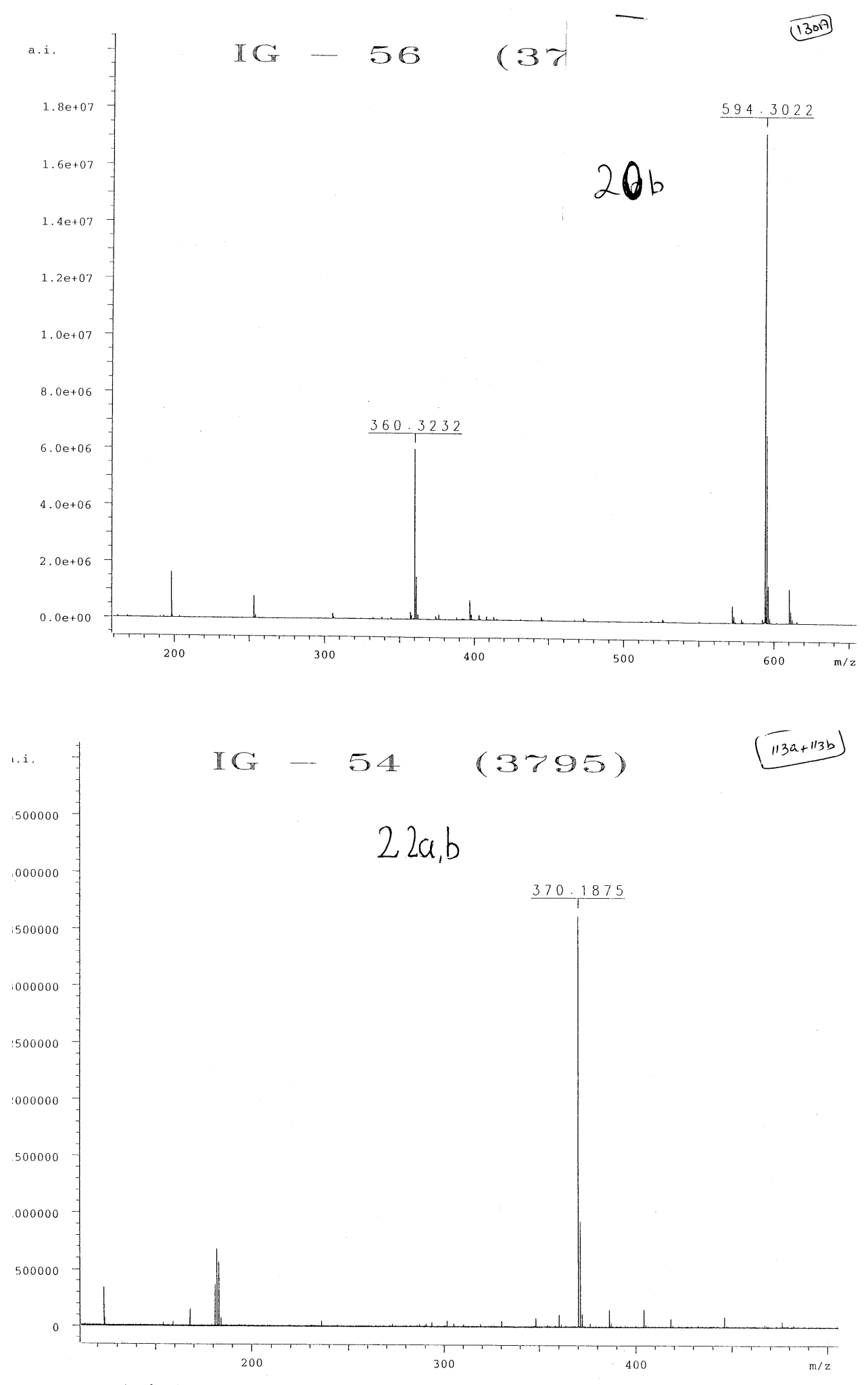

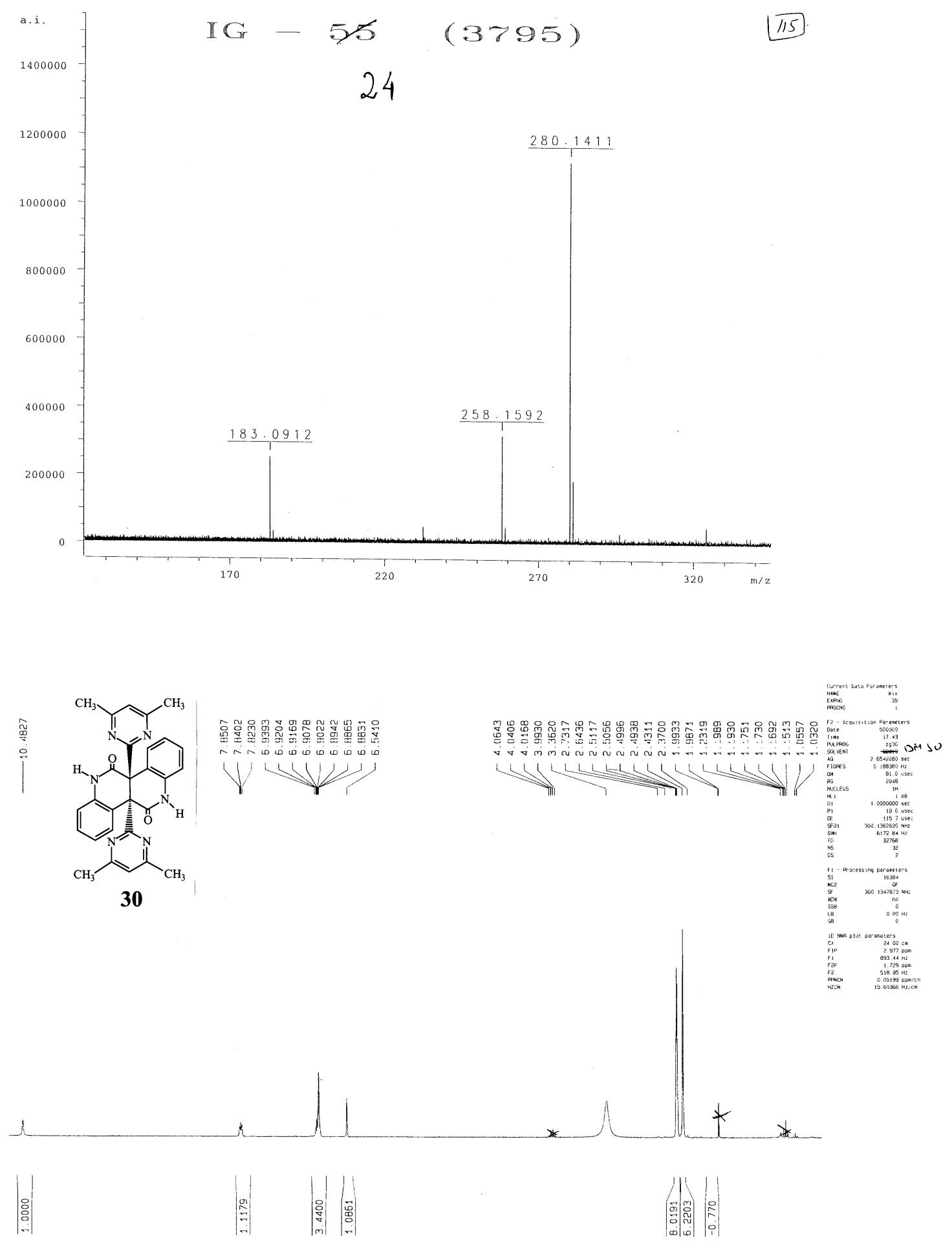

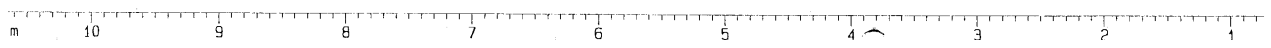




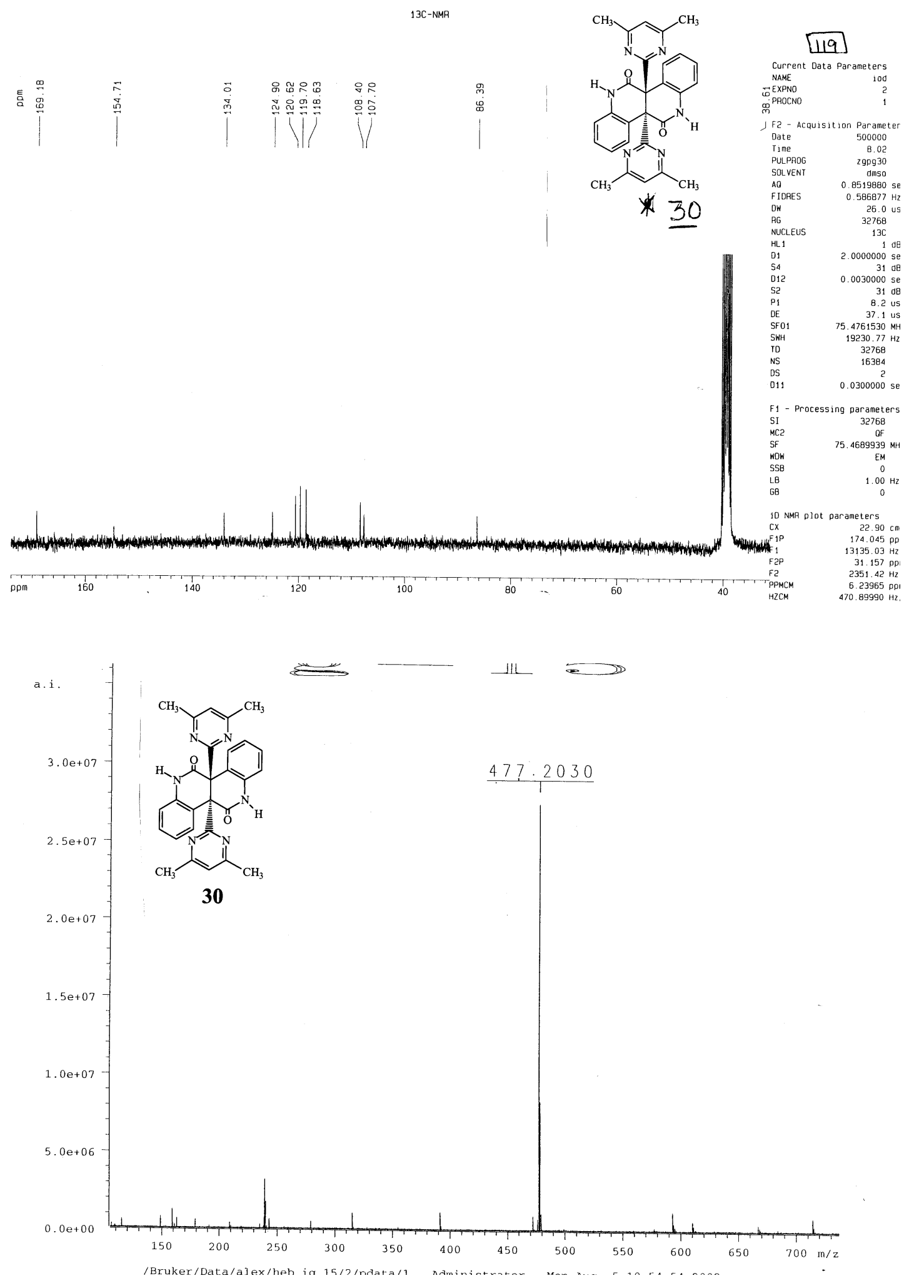




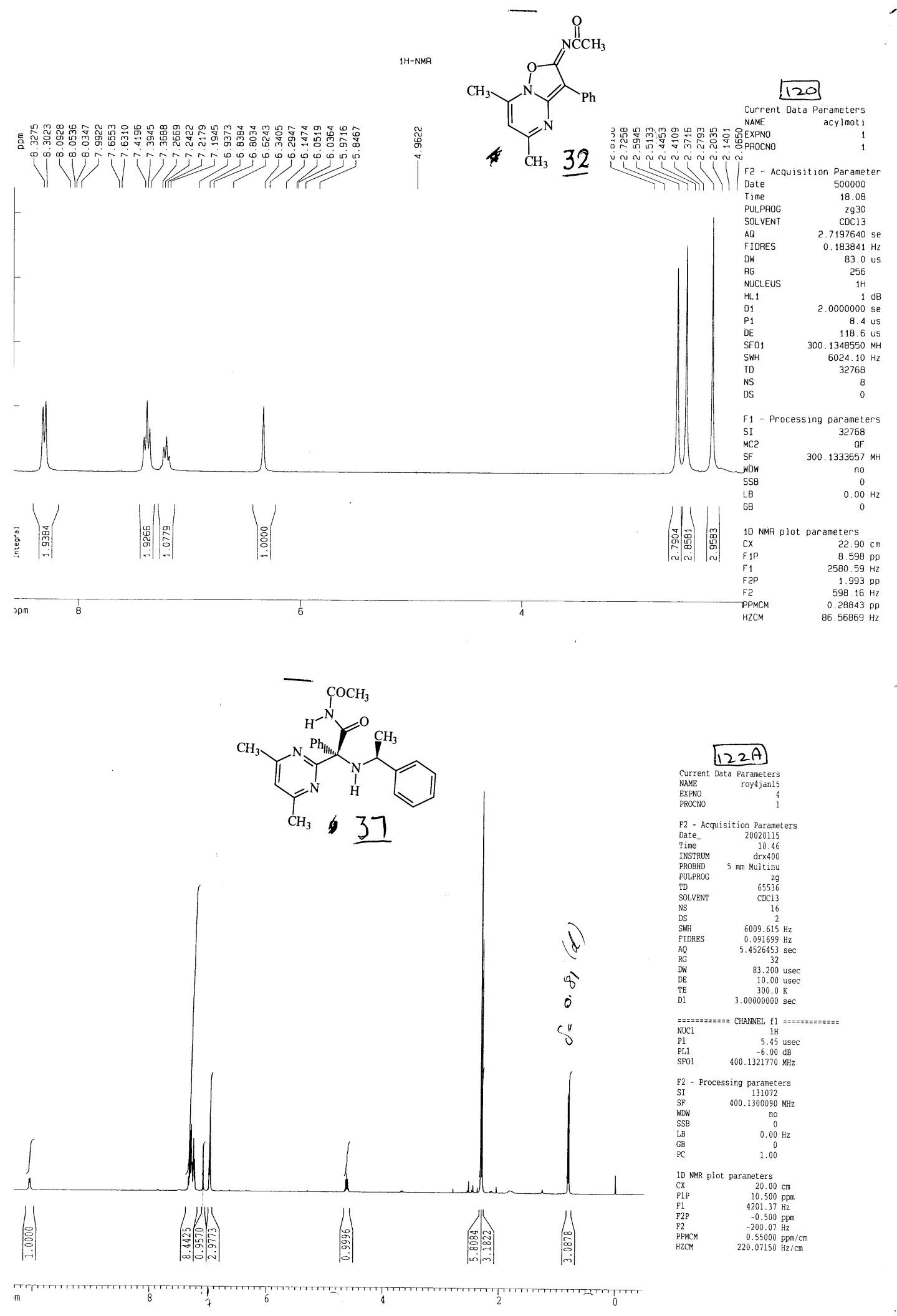



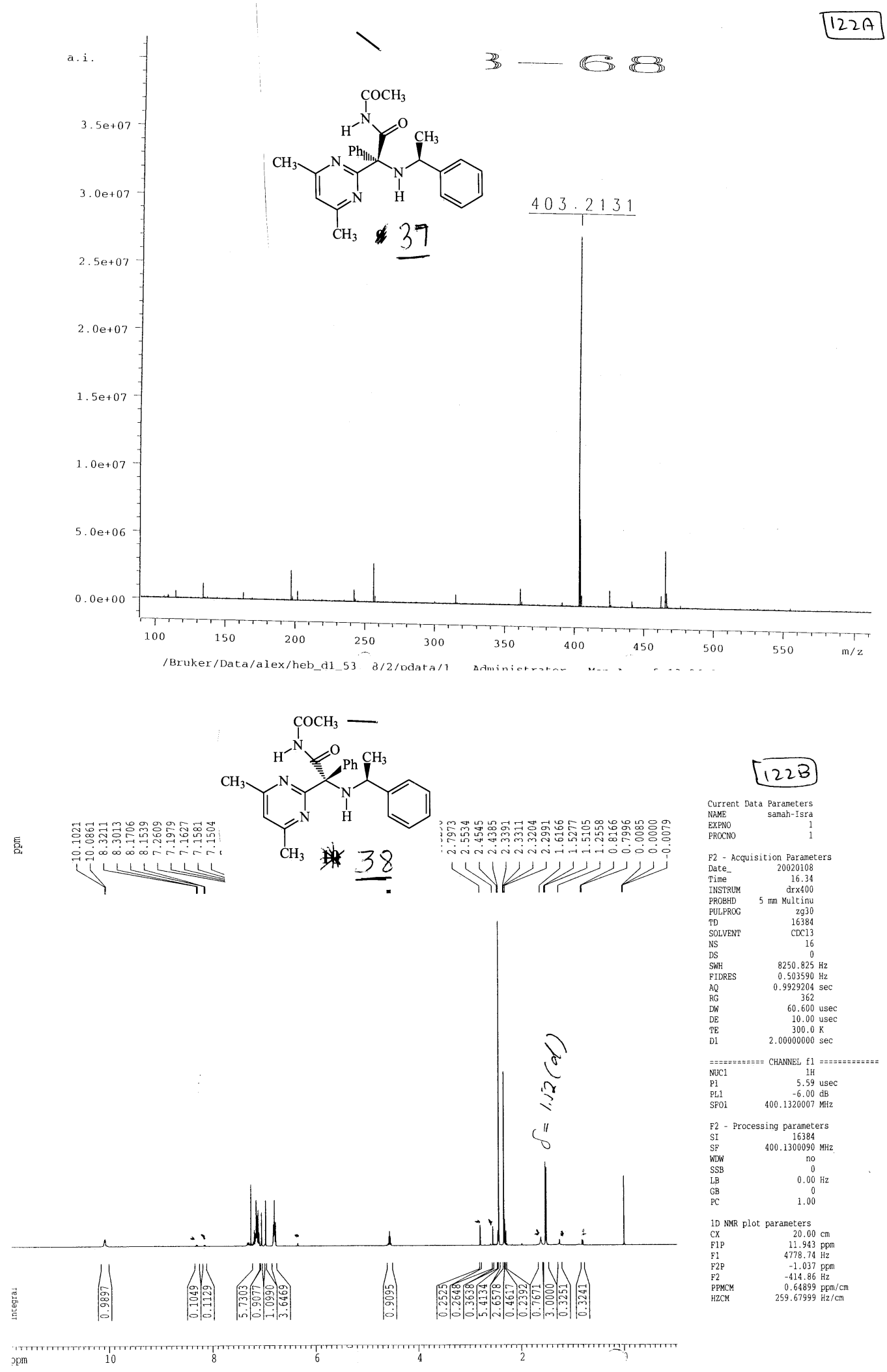

Pictures of models made to determine the spatial influence on the chemical shifts of the methyl groups in 37-40: 

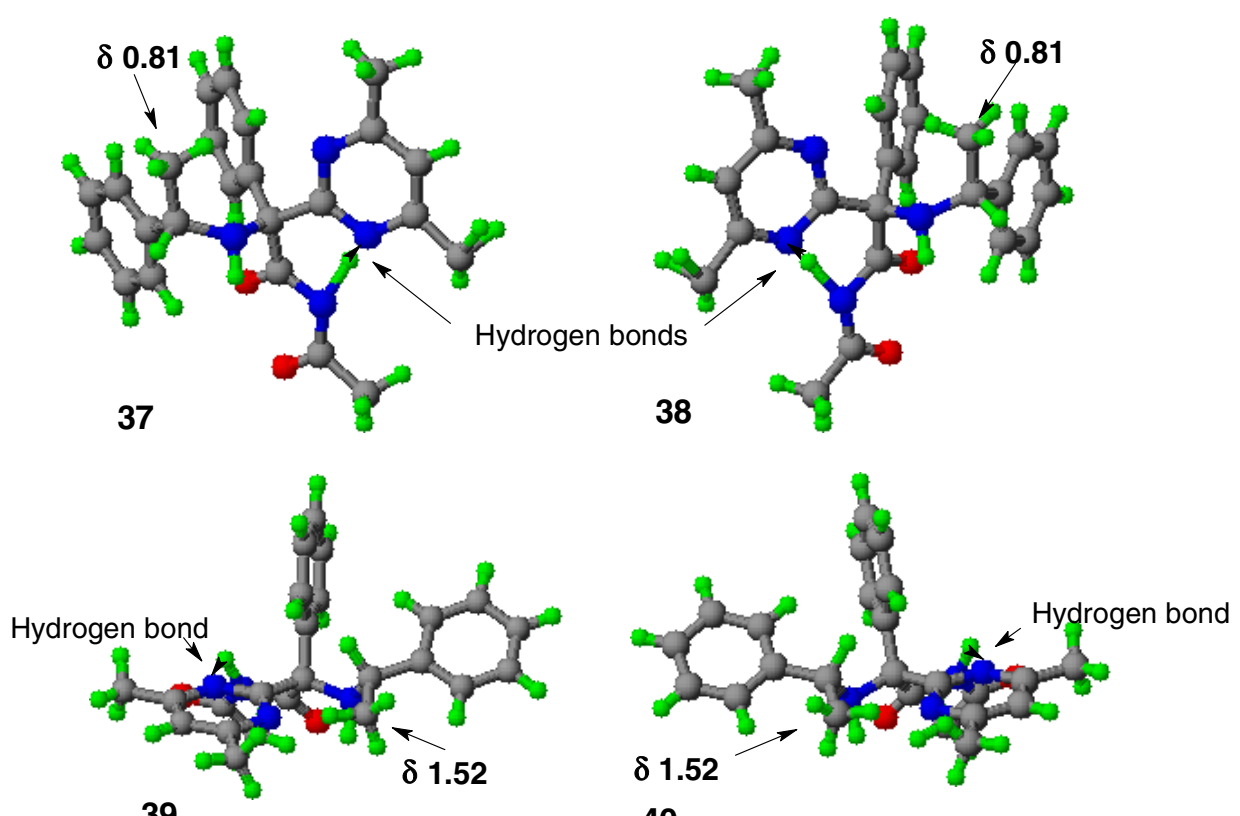

40

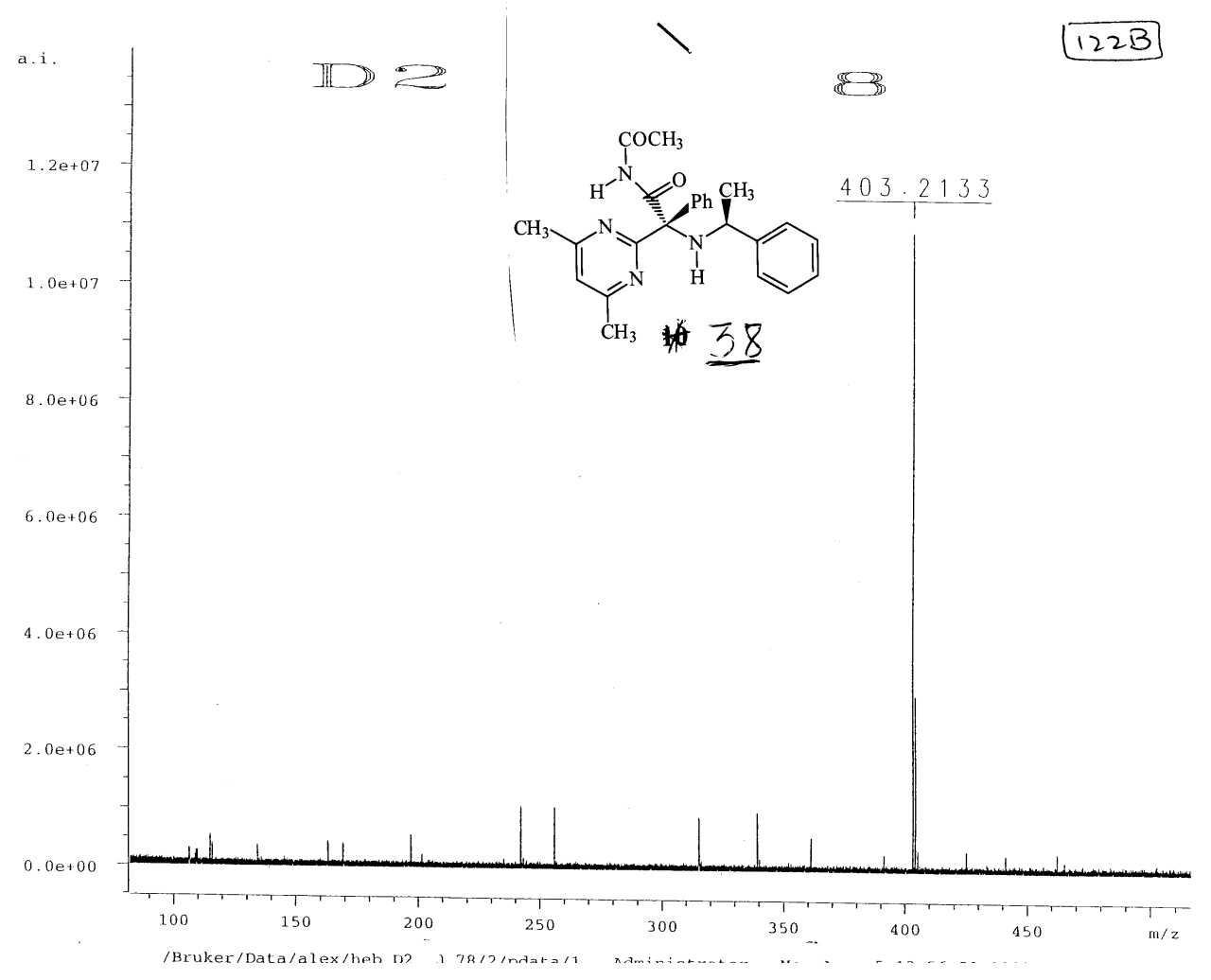



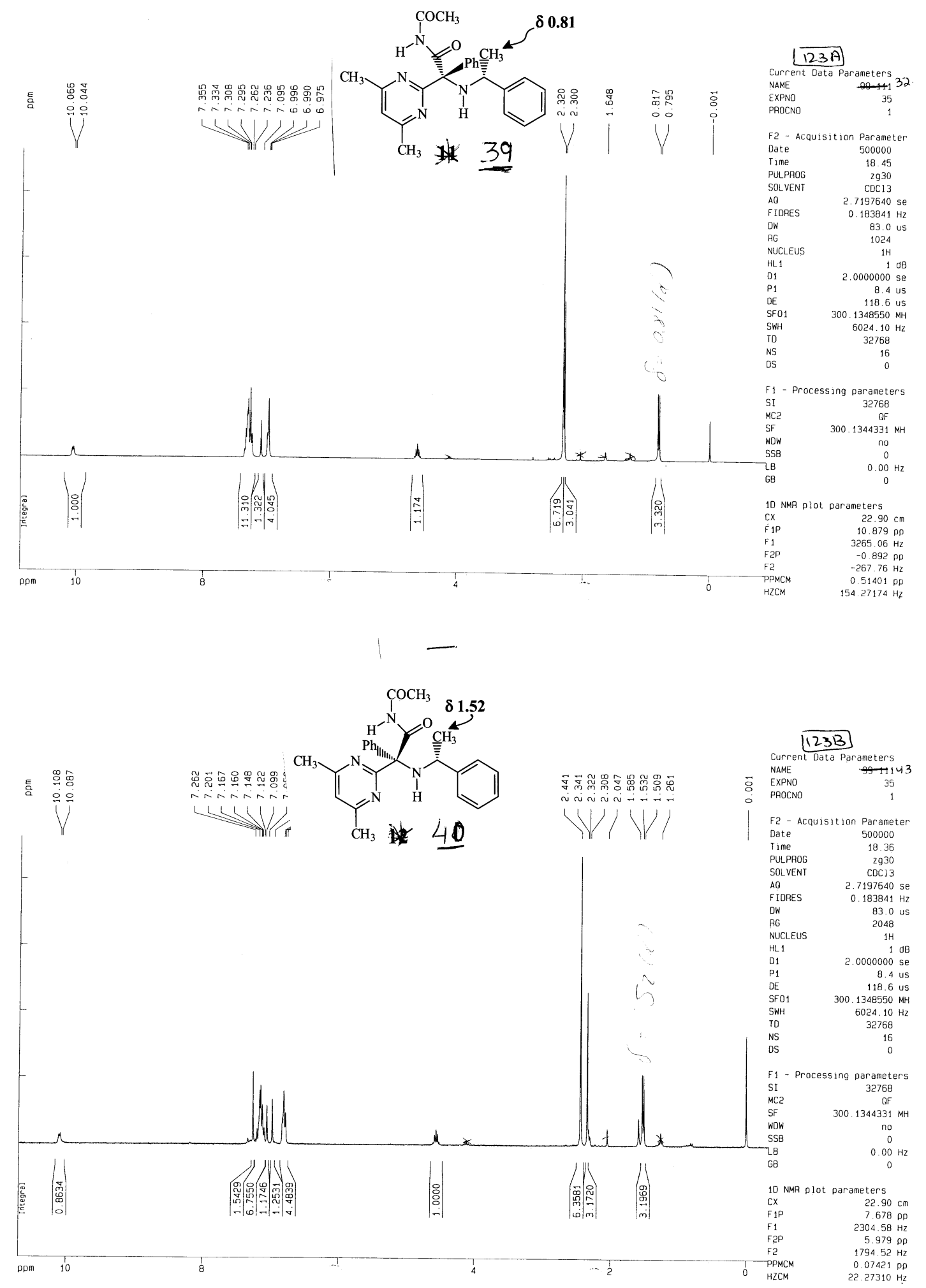

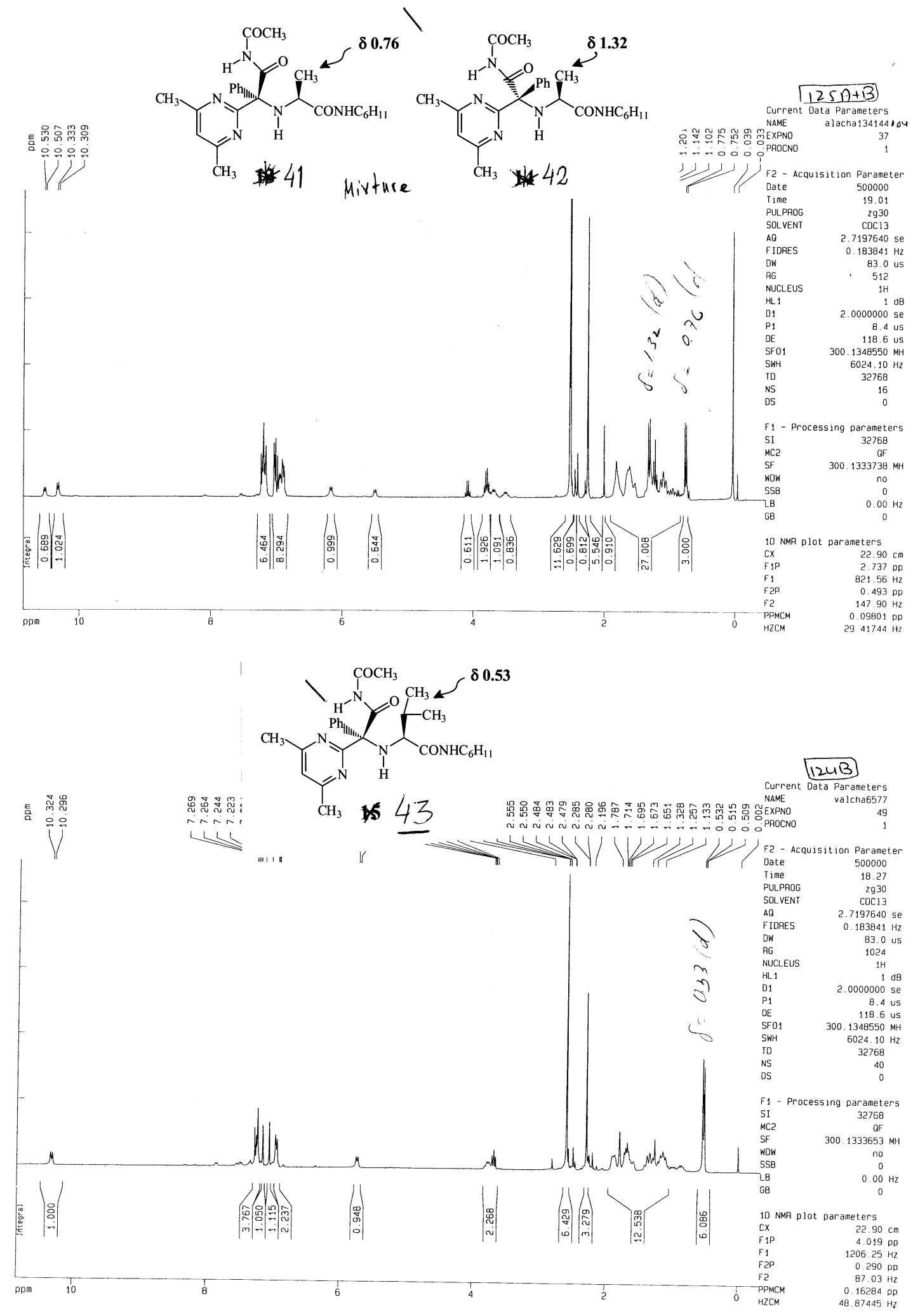

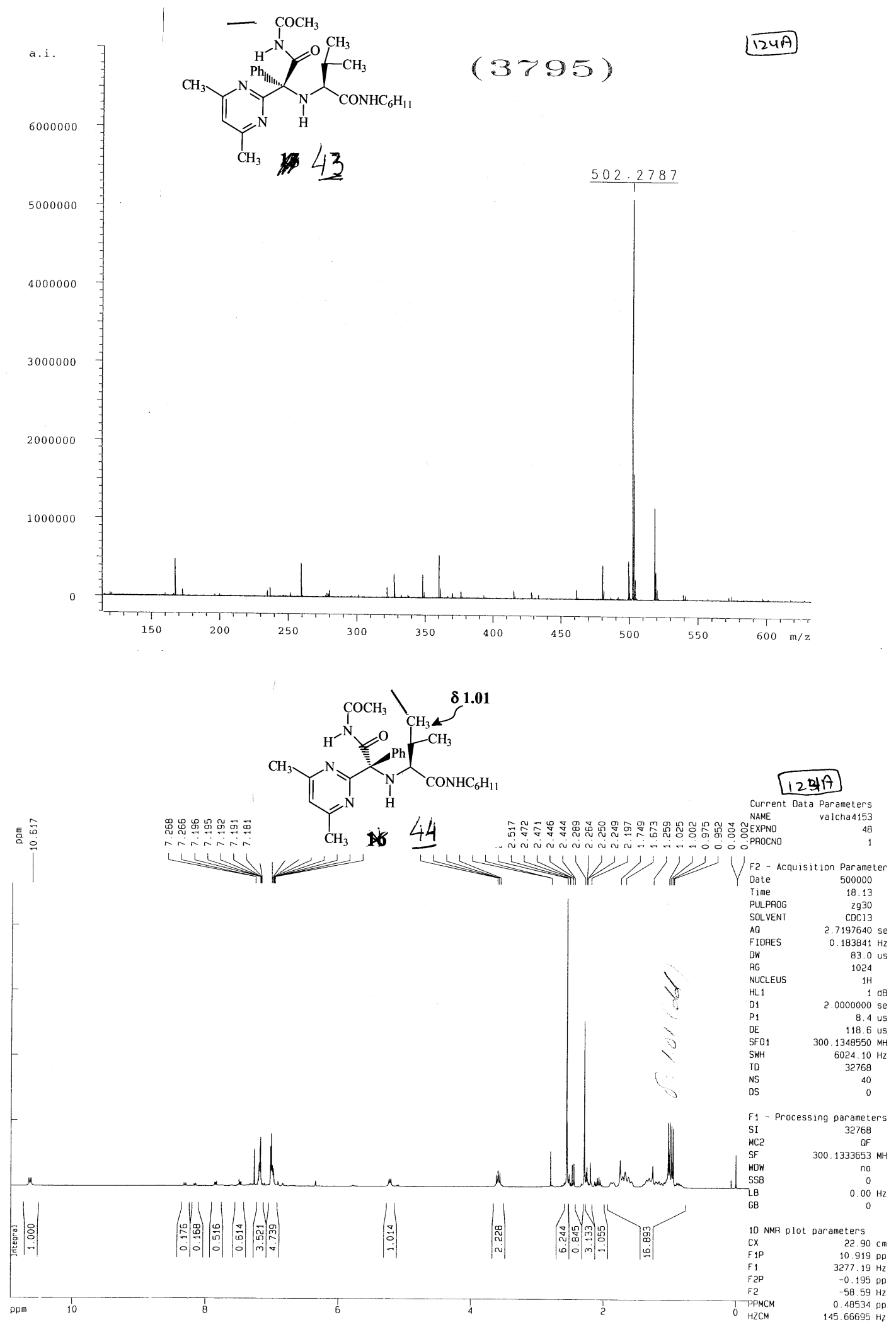


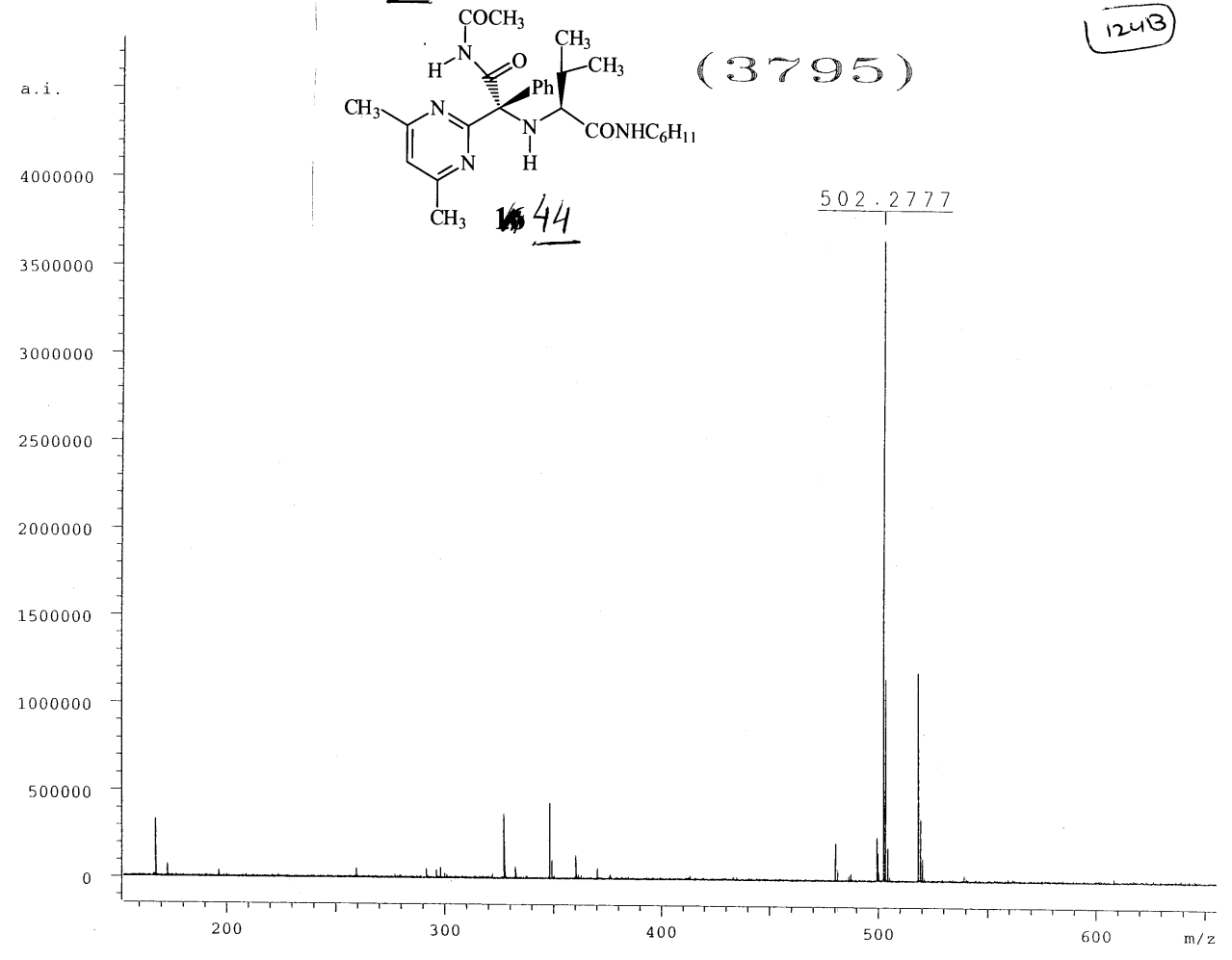

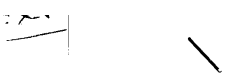

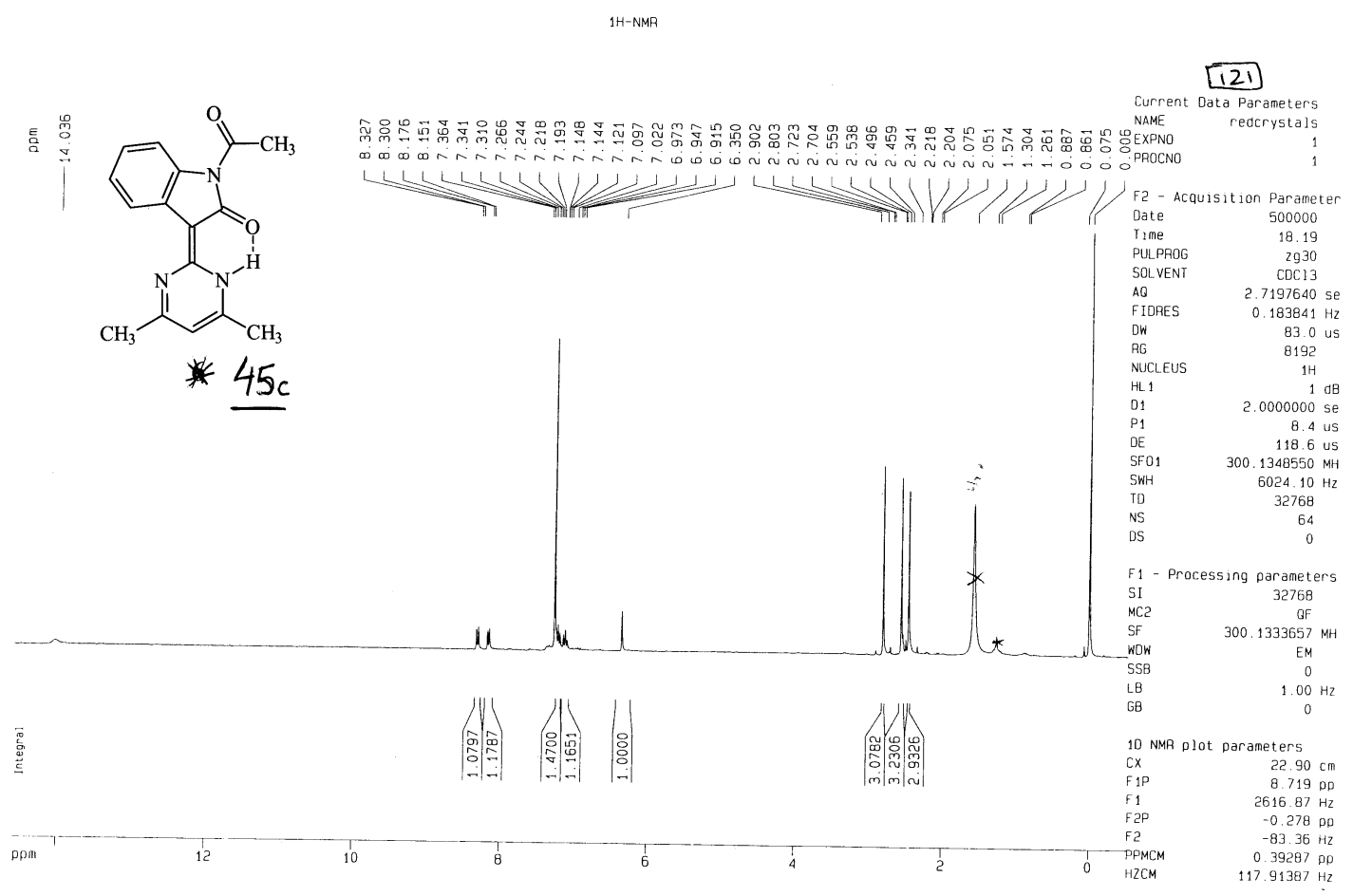




\section{X-ray data and OTREP for 45c:}

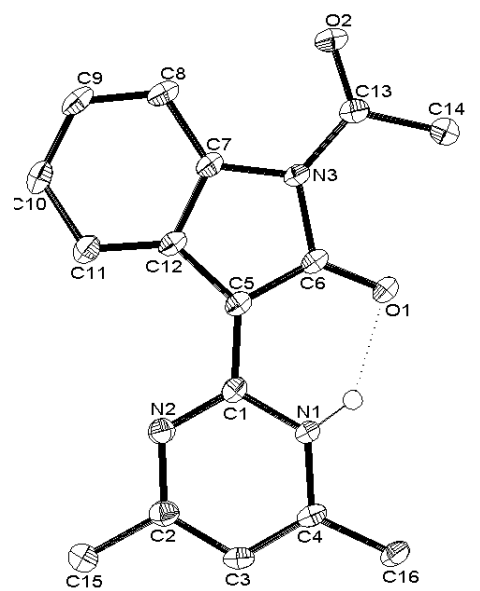

A single crystal was coated with vaseline, attached to a glass fiber, and transferred to a Bruker SMART APEX CCD X-ray diffractometer system controlled by a pentium-based PC running the SMART software package $^{1}$. The crystal was mounted on the three-circle goniometer with $\chi$ fixed at $+54.72^{\mathrm{O}}$ and was rapidly cooled to $-150{ }^{\circ} \mathrm{C}$ with a Bruker KRYOFLEX nitrogen cryostat. The diffracted graphitemonochromated Mo K $\alpha$ radiation $(\lambda=0.71073 \AA$ ) was detected on a phosphor screen held at a distance of $6.0 \mathrm{~cm}$ from the crystal operating at $-44{ }^{\circ} \mathrm{C}$. A detector array of 512 X 512 pixels, with a pixel size of approximately $120 \mu \mathrm{m}$, was employed for data collection. The detector centroid and crystal-to-detector distance were calibrated from a least-squares analysis of the unit cell parameters of a carefully centered YLID reference crystal.

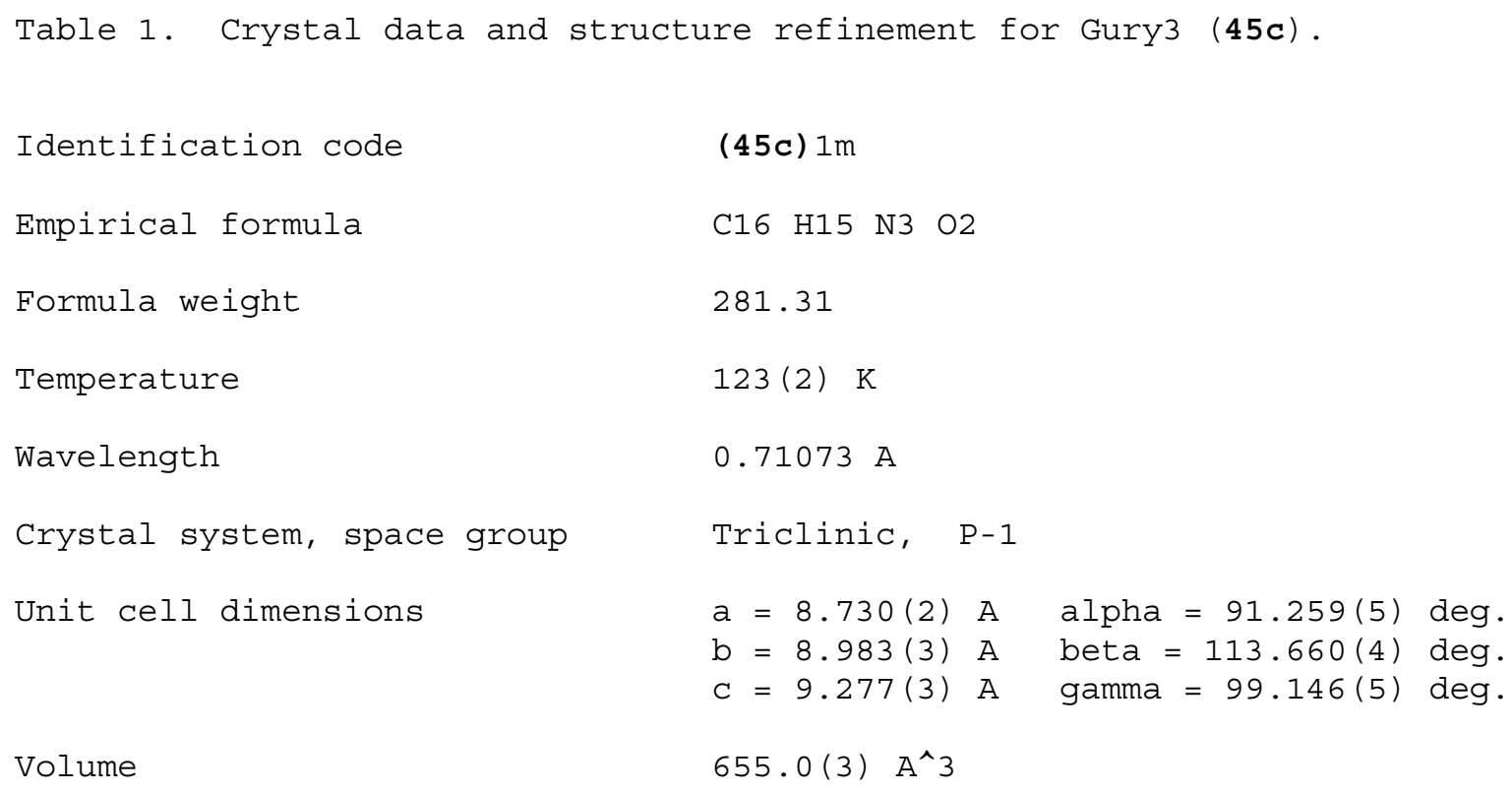




$$
\begin{aligned}
& \text { Z, Calculated density } \\
& 2, \quad 1.426 \mathrm{Mg} / \mathrm{m}^{\wedge} 3 \\
& \text { Absorption coefficient } \\
& 0.097 \mathrm{~mm}^{\wedge}-1 \\
& F(000) \\
& 296 \\
& \text { Crystal size } \\
& 0.27 \times 0.15 \times 0.09 \mathrm{~mm} \\
& \text { Theta range for data collection } \\
& 2.31 \text { to } 28.09 \text { deg. } \\
& \text { Limiting indices } \\
& -11<=\mathrm{h}<=11, \quad-11<=\mathrm{k}<=11, \quad-12<=1<=12 \\
& \text { Reflections collected / unique } \\
& 7800 / 3062 \text { [R(int) }=0.0530] \\
& \text { Completeness to theta }=28.09 \\
& 96.1 \% \\
& \text { Absorption correction } \\
& \text { None } \\
& \text { Max. and min. transmission } \\
& 0.9913 \text { and } 0.9743 \\
& \text { Refinement method } \\
& \text { Full-matrix least-squares on } \mathrm{F}^{\wedge} 2 \\
& \text { Data / restraints / parameters } \\
& 3062 / 0 / 251 \\
& \text { Goodness-of-fit on } \mathrm{F}^{\wedge} 2 \\
& 1.011 \\
& \text { Final } R \text { indices [I>2sigma(I)] } \\
& \mathrm{R} 1=0.0451, \mathrm{wR} 2=0.1137 \\
& \mathrm{R} \text { indices (all data) } \\
& \mathrm{R} 1=0.0577, \mathrm{wR} 2=0.1212 \\
& \text { Extinction coefficient } \\
& 0.002(3) \\
& \text { Largest diff. peak and hole } \\
& 0.248 \text { and }-0.276 \text { e.A^-3 }
\end{aligned}
$$

\begin{tabular}{|c|c|c|c|c|}
\hline & $x$ & $\mathrm{Y}$ & $\mathrm{z}$ & $\mathrm{U}(\mathrm{eq})$ \\
\hline$C(1)$ & $7965(2)$ & $5422(2)$ & $5323(2)$ & $17(1)$ \\
\hline$C(2)$ & $10022(2)$ & $7534(2)$ & $6474(2)$ & $21(1)$ \\
\hline$C(3)$ & $10194(2)$ & $7759(2)$ & $5048(2)$ & $21(1)$ \\
\hline$C(4)$ & $9228(2)$ & $6759(2)$ & $3764(2)$ & $19(1)$ \\
\hline$C(5)$ & $6781(2)$ & $4193(2)$ & $5350(2)$ & $18(1)$ \\
\hline$C(6)$ & $5783(2)$ & $3166(2)$ & $3994(2)$ & $18(1)$ \\
\hline$C(7)$ & $5028(2)$ & $2429(2)$ & $6017(2)$ & $18(1)$ \\
\hline$C(8)$ & $4316(2)$ & $1684(2)$ & $6955(2)$ & $23(1)$ \\
\hline$C(9)$ & $4895(2)$ & $2273(2)$ & $8512(2)$ & $25(1)$ \\
\hline$C(10)$ & $6130(2)$ & $3562(2)$ & $9112(2)$ & $25(1)$ \\
\hline$C(11)$ & $6857(2)$ & $4289(2)$ & $8176(2)$ & $22(1)$ \\
\hline$C(12)$ & $6309(2)$ & $3725(2)$ & $6617(2)$ & $18(1)$ \\
\hline$C(13)$ & $3342(2)$ & $1003(2)$ & $3377(2)$ & $20(1)$ \\
\hline$C(14)$ & $2927(2)$ & $970(2)$ & $1655(2)$ & $28(1)$ \\
\hline$C(15)$ & $11099(2)$ & $8580(2)$ & $7912(2)$ & $26(1)$ \\
\hline
\end{tabular}

Table 2. Atomic coordinates ( $\left.\mathrm{x} 10^{\wedge} 4\right)$ and equivalent isotropic displacement parameters $\left(A^{\wedge} 2 \times 10^{\wedge} 3\right)$ for Gury3 (45c). $\mathrm{U}(\mathrm{eq})$ is defined as one third of the trace of the orthogonalized Uij tensor. 


$\begin{array}{lllll}\mathrm{C}(16) & 9292(2) & 6827(2) & 2193(2) & 24(1) \\ \mathrm{N}(1) & 8139(2) & 5604(1) & 3934(1) & 18(1) \\ \mathrm{N}(2) & 8929(1) & 6399(1) & 6613(1) & 20(1) \\ \mathrm{N}(3) & 4668(1) & 2098(1) & 4403(1) & 18(1) \\ \mathrm{O}(1) & 5832(1) & 3125(1) & 2674(1) & 23(1) \\ \mathrm{O}(2) & 2522(1) & 119(1) & 3885(1) & 28(1)\end{array}$

Table 3. Bond lengths [A] and angles [deg] for Gury3 (45c).

$\begin{array}{ll}\mathrm{C}(1)-\mathrm{N}(2) & 1.3496(18) \\ \mathrm{C}(1)-\mathrm{N}(1) & 1.3671(17) \\ \mathrm{C}(1)-\mathrm{C}(5) & 1.3954(19) \\ \mathrm{C}(2)-\mathrm{N}(2) & 1.3278(18) \\ \mathrm{C}(2)-\mathrm{C}(3) & 1.4055(19) \\ \mathrm{C}(2)-\mathrm{C}(15) & 1.484(2) \\ \mathrm{C}(3)-\mathrm{C}(4) & 1.358(2) \\ \mathrm{C}(4)-\mathrm{N}(1) & 1.3483(17) \\ \mathrm{C}(4)-\mathrm{C}(16) & 1.4829(19) \\ \mathrm{C}(5)-\mathrm{C}(6) & 1.416(2) \\ \mathrm{C}(5)-\mathrm{C}(12) & 1.4428(18) \\ \mathrm{C}(6)-\mathrm{O}(1) & 1.2424(16) \\ \mathrm{C}(6)-\mathrm{N}(3) & 1.4245(17) \\ \mathrm{C}(7)-\mathrm{C}(8) & 1.3856(19) \\ \mathrm{C}(7)-\mathrm{C}(12) & 1.4046(19) \\ \mathrm{C}(7)-\mathrm{N}(3) & 1.4148(18) \\ \mathrm{C}(8)-\mathrm{C}(9) & 1.384(2) \\ \mathrm{C}(9)-\mathrm{C}(10) & 1.381(2) \\ \mathrm{C}(10)-\mathrm{C}(11) & 1.3848(19) \\ \mathrm{C}(11)-\mathrm{C}(12) & 1.384(2) \\ \mathrm{C}(13)-\mathrm{O}(2) & 1.2127(16) \\ \mathrm{C}(13)-\mathrm{N}(3) & 1.3879(18) \\ \mathrm{C}(13)-\mathrm{C}(14) & 1.489(2)\end{array}$

$\begin{array}{ll}N(2)-C(1)-N(1) & 120.30(12) \\ N(2)-C(1)-C(5) & 122.08(12) \\ N(1)-C(1)-C(5) & 117.62(12) \\ N(2)-C(2)-C(3) & 122.74(13) \\ N(2)-C(2)-C(15) & 117.17(13) \\ C(3)-C(2)-C(15) & 120.09(13) \\ C(4)-C(3)-C(2) & 118.81(13) \\ N(1)-C(4)-C(3) & 117.51(13) \\ N(1)-C(4)-C(16) & 117.41(12) \\ C(3)-C(4)-C(16) & 125.07(13) \\ C(1)-C(5)-C(6) & 121.73(12) \\ C(1)-C(5)-C(12) & 130.16(13) \\ C(6)-C(5)-C(12) & 108.10(12) \\ O(1)-C(6)-C(5) & 128.95(13) \\ O(1)-C(6)-N(3) & 123.66(13) \\ C(5)-C(6)-N(3) & 107.38(11) \\ C(8)-C(7)-C(12) & 121.68(13) \\ C(8)-C(7)-N(3) & 129.66(13) \\ C(12)-C(7)-N(3) & 108.66(11) \\ C(9)-C(8)-C(7) & 117.63(14) \\ C(10)-C(9)-C(8) & 121.43(13) \\ C(9)-C(10)-C(11) & 120.71(14) \\ C(12)-C(11)-C(10) & 119.22(14) \\ C(11)-C(12)-C(7) & 119.30(12) \\ C(11)-C(12)-C(5) & 133.30(13) \\ C(7)-C(12)-C(5) & 107.40(12) \\ O(2)-C(13)-N(3) & 120.03(13) \\ & \\ C & \end{array}$




$\begin{array}{ll}O(2)-C(13)-C(14) & 121.26(13) \\ N(3)-C(13)-C(14) & 118.69(12) \\ C(4)-N(1)-C(1) & 122.83(12) \\ C(2)-N(2)-C(1) & 117.79(12) \\ C(13)-N(3)-C(7) & 124.92(11) \\ C(13)-N(3)-C(6) & 126.42(11) \\ C(7)-N(3)-C(6) & 108.40(11)\end{array}$

Table 4. Anisotropic displacement parameters ( $A^{\wedge} 2 \times 10^{\wedge} 3$ ) for Gury3 (45c). The anisotropic displacement factor exponent takes the form: $-2 \mathrm{pi}^{\wedge} 2\left[\mathrm{~h}^{\wedge} 2 \mathrm{a}{ }^{\wedge} 2 \mathrm{U} 11+\ldots+2 \mathrm{hk} \mathrm{a}^{*} \mathrm{~b} * \mathrm{U} 12\right]$

\begin{tabular}{|c|c|c|c|c|c|c|}
\hline & U11 & U22 & U33 & U23 & U13 & $\mathrm{U} 12$ \\
\hline$C(1)$ & $18(1)$ & $19(1)$ & $17(1)$ & $4(1)$ & $10(1)$ & $6(1)$ \\
\hline$C(2)$ & $20(1)$ & $19(1)$ & $25(1)$ & $3(1)$ & $11(1)$ & $4(1)$ \\
\hline$C(3)$ & $21(1)$ & $17(1)$ & $27(1)$ & $4(1)$ & $12(1)$ & $-1(1)$ \\
\hline$C(4)$ & $20(1)$ & $18(1)$ & $24(1)$ & $8(1)$ & $13(1)$ & $4(1)$ \\
\hline$C(5)$ & $18(1)$ & $20(1)$ & $19(1)$ & $4(1)$ & $10(1)$ & $4(1)$ \\
\hline$C(6)$ & $19(1)$ & $19(1)$ & $20(1)$ & $6(1)$ & $12(1)$ & $5(1)$ \\
\hline$C(7)$ & $18(1)$ & $21(1)$ & $19(1)$ & $7(1)$ & $10(1)$ & $5(1)$ \\
\hline$C(8)$ & $22(1)$ & $26(1)$ & $25(1)$ & $9(1)$ & $14(1)$ & $4(1)$ \\
\hline$C(9)$ & $29(1)$ & $31(1)$ & $24(1)$ & $12(1)$ & $18(1)$ & $8(1)$ \\
\hline$C(10)$ & $32(1)$ & $31(1)$ & $17(1)$ & $5(1)$ & $13(1)$ & $8(1)$ \\
\hline$C(11)$ & $26(1)$ & $24(1)$ & $20(1)$ & $4(1)$ & $12(1)$ & $5(1)$ \\
\hline$C(12)$ & $18(1)$ & $20(1)$ & $20(1)$ & $7(1)$ & $12(1)$ & $6(1)$ \\
\hline$C(13)$ & $20(1)$ & $19(1)$ & $25(1)$ & $4(1)$ & $12(1)$ & $3(1)$ \\
\hline$C(14)$ & $28(1)$ & $28(1)$ & $23(1)$ & $-2(1)$ & $11(1)$ & $-6(1)$ \\
\hline$C(15)$ & $27(1)$ & $24(1)$ & $25(1)$ & $0(1)$ & $10(1)$ & $-1(1)$ \\
\hline$C(16)$ & $26(1)$ & $26(1)$ & 22 (1) & $7(1)$ & $14(1)$ & $2(1)$ \\
\hline $\mathrm{N}(1)$ & $20(1)$ & $18(1)$ & $17(1)$ & $3(1)$ & $10(1)$ & $-1(1)$ \\
\hline $\mathrm{N}(2)$ & $21(1)$ & $18(1)$ & $21(1)$ & $2(1)$ & $10(1)$ & $2(1)$ \\
\hline$N(3)$ & $19(1)$ & $20(1)$ & $18(1)$ & $4(1)$ & $11(1)$ & $1(1)$ \\
\hline$O(1)$ & $26(1)$ & $26(1)$ & $18(1)$ & $3(1)$ & $13(1)$ & $0(1)$ \\
\hline$O(2)$ & $29(1)$ & $26(1)$ & $31(1)$ & $5(1)$ & $17(1)$ & $-4(1)$ \\
\hline
\end{tabular}

Table 5. Hydrogen coordinates $\left(x 10^{\wedge} 4\right)$ and isotropic displacement parameters $\left(A^{\wedge} 2 \times 10^{\wedge} 3\right)$ for Gury3 (45c).

\begin{tabular}{|c|c|c|c|c|}
\hline & $\mathrm{x}$ & $\mathrm{y}$ & $z$ & $\mathrm{U}($ eq $)$ \\
\hline $\mathrm{H}(3)$ & $11000(20)$ & $8614(19)$ & $5030(20)$ & $34(5)$ \\
\hline $\mathrm{H}(8)$ & $3470(20)$ & $780(20)$ & $6570(20)$ & $32(4)$ \\
\hline $\mathrm{H}(9)$ & $4360(20)$ & $1709(18)$ & 9196 (19) & $30(4)$ \\
\hline $\mathrm{H}(10)$ & $6530(18)$ & $3944(16)$ & 10229 (19) & $20(4)$ \\
\hline $\mathrm{H}(11)$ & $7746(19)$ & $5195(17)$ & $8596(17)$ & $20(4)$ \\
\hline $\mathrm{H}(14 \mathrm{~A})$ & $2760(20)$ & $1970(20)$ & $1280(20)$ & $49(5)$ \\
\hline $\mathrm{H}(14 \mathrm{~B})$ & $3790(30)$ & $650(20)$ & $1390(20)$ & $51(6)$ \\
\hline $\mathrm{H}(14 \mathrm{C})$ & $1890(30)$ & $290(20)$ & $1090(20)$ & $51(6)$ \\
\hline $\mathrm{H}(15 \mathrm{~A})$ & $10880(20)$ & $9560(20)$ & $7660(20)$ & $44(5)$ \\
\hline $\mathrm{H}(15 \mathrm{~B})$ & $12280(20)$ & $8630(20)$ & $8120(20)$ & $43(5)$ \\
\hline $\mathrm{H}(15 \mathrm{C})$ & $10910(20)$ & $8290(20)$ & $8840(20)$ & $51(6)$ \\
\hline $\mathrm{H}(16 \mathrm{~A})$ & $8200(20)$ & $6919(18)$ & $1390(20)$ & $36(5)$ \\
\hline $\mathrm{H}(16 \mathrm{~B})$ & $9610(20)$ & $5918(19)$ & $1930(19)$ & $33(4)$ \\
\hline $\mathrm{H}(16 \mathrm{C})$ & $10120(20)$ & $7660(20)$ & $2190(20)$ & $42(5)$ \\
\hline
\end{tabular}




\begin{tabular}{lllll}
$\mathrm{H}(1 \mathrm{~N} 1)$ & $7429(19)$ & $4922(18)$ & $3134(19)$ & $23(4)$ \\
\hline
\end{tabular}

Table 6. Hydrogen bonds for Gury3 (45c) [A and deg.].

\begin{tabular}{lllll}
\hline $\mathrm{D}-\mathrm{H} \ldots \mathrm{A}$ & $\mathrm{d}(\mathrm{D}-\mathrm{H})$ & $\mathrm{d}(\mathrm{H} \ldots \mathrm{A})$ & $\mathrm{d}(\mathrm{D} \ldots \mathrm{A})$ & $<(\mathrm{DHA})$ \\
$\mathrm{N}(1)-\mathrm{H}(1 \mathrm{~N} 1) \ldots \mathrm{O}(1)$ & $0.89(2)$ & $1.87(2)$ & $2.637(2)$ & $142(1)$ \\
\hline
\end{tabular}

\section{X-ray data for 34:}

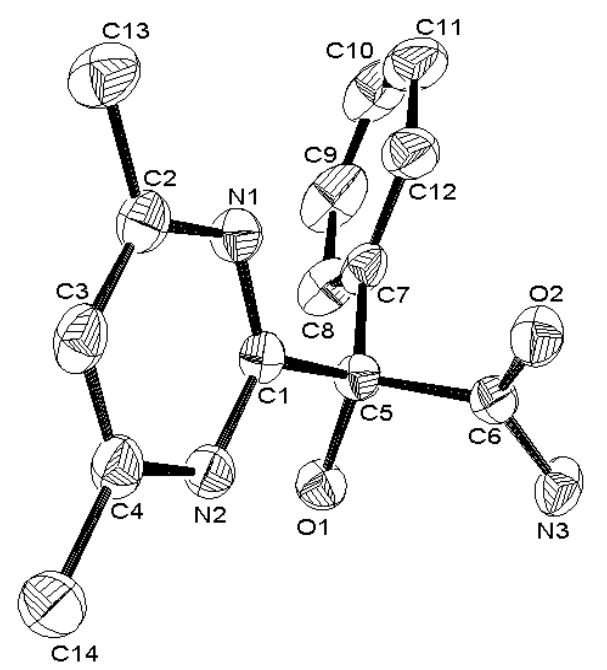

A single crystal was coated with vaseline, attached to a glass fiber, and transferred to a Bruker SMART APEX CCD X-ray diffractometer system controlled by a pentium-based PC running the SMART software package $^{1}$. The crystal was mounted on the three-circle goniometer with $\chi$ fixed at $+54.72^{\mathrm{O}}$ and was rapidly cooled to $-73{ }^{\mathrm{O}} \mathrm{C}$ with a Bruker KRYOFLEX nitrogen cryostat. The diffracted graphitemonochromated Mo K $\alpha$ radiation $(\lambda=0.71073 \AA)$ was detected on a phosphor screen held at a distance of $6.0 \mathrm{~cm}$ from the crystal operating at $-44{ }^{\mathrm{O}} \mathrm{C}$. A detector array of 512 X 512 pixels, with a pixel size of approximately $120 \mu \mathrm{m}$, was employed for data collection. The detector centroid and crystal-to-detector distance were calibrated from a least-squares analysis of the unit cell parameters of a carefully centered YLID reference crystal.

After the crystal of 'Guri2 (34)' had been carefully optically centered within the X-ray beam, a series of 30 data frames measured at $0.3^{\mathrm{O}}$ increments of $\omega$ were collected with three different $2 \theta$ and $\varphi$ values to assess the overall crystal quality and to calculate a preliminary unit cell. In order to correct for highenergy background events in the images, data frames were collected as the sum of two 5 sec exposures and noncorrelating events were eliminated. A correction for the background detector current was also applied to the frames, and a small offset was added to all of the individual pixel values to prevent any statistical bias induced by truncating negative values to zero. The measured intensities of individual reflections were plotted at $0.3^{\mathrm{O}}$ intervals of $\omega$, and the average peak width at baseline was less than $1.5^{\mathrm{O}}$. A total of 63 reflections with $\mathrm{I}>20 \sigma(\mathrm{I})$ were selected from the data frames and utilized to calculate a preliminary unit cell. For the collection of the intensity data, the detector was positioned at a $2 \theta$ value of $28^{\mathrm{O}}$ and the intensity images were measured at $0.3^{\mathrm{O}}$ intervals of $\omega$ for a duration of $20 \mathrm{sec}$ each. The data frames were collected in four distinct shells which, when combined, measured more than 1.3 hemispheres of intensity data with a maximum $2 \theta$ of $46.5^{\circ}$. For the first shell, the crystal was positioned at $\varphi=0^{\mathrm{O}}$ and $\omega=-28^{\mathrm{O}}$ and a set of 600 frames were collected. A series of 600 frames was collected in the second shell 
with a starting position of $\varphi=90^{\circ}$ and $\omega=-28.0^{\circ}$. The crystal was then moved to a position of $\varphi=180^{\circ}$ and $\omega=-28.0^{\circ}$ to measure 600 frames required for the third shell. The last 600 frames in the forth shell were collected starting at $\varphi=270^{\circ}$ and $\omega=-28^{\circ}$. The initial 50 frames of the first data shell were recollected at the end of data collection to correct for any crystal decay, but none was observed.

Immediately after collection, the raw data frames were transferred to a second PC computer for integration by the SAINT program package ${ }^{2}$. The background frame information was updated according to the equation $\mathrm{B}^{\prime}=(7 \mathrm{~B}+\mathrm{C}) / 8$, where $\mathrm{B}^{\prime}$ is the update pixel value, $\mathrm{B}$ is the background pixel value before updating, and $\mathrm{C}$ is the pixel value in the current frame. The integration was also corrected for spatial distortion induced by the detector. In addition, pixels that reside outside the detector active area or behind the beam stop were masked during frame integration. The integrated intensities for the four shells of data were merged to one reflection file. The data file was filtered to reject outlier reflections. The rejection of a reflection was based on the disagreement between the intensity of the reflection and the average intensity of the symmetry equivalents to which the reflection belongs. In the case of strong reflections (I $>99 \sigma(\mathrm{I})$ ) which contains only two equivalents, the larger of the two equivalents was retains.

The structure was solved and refined by the SHELXTL software package ${ }^{3}$.

1. SMART-NT V5.6, BRUKER AXS GMBH, D-76181 Karlsruhe, Germany, 2002.

2. SAINT-NT V5.0, BRUKER AXS GMBH, D-76181 Karlsruhe, Germany, 2002.

3. SHELXTL-NT V6.1, BRUKER AXS GMBH, D-76181 Karlsruhe, Germany, 2002.

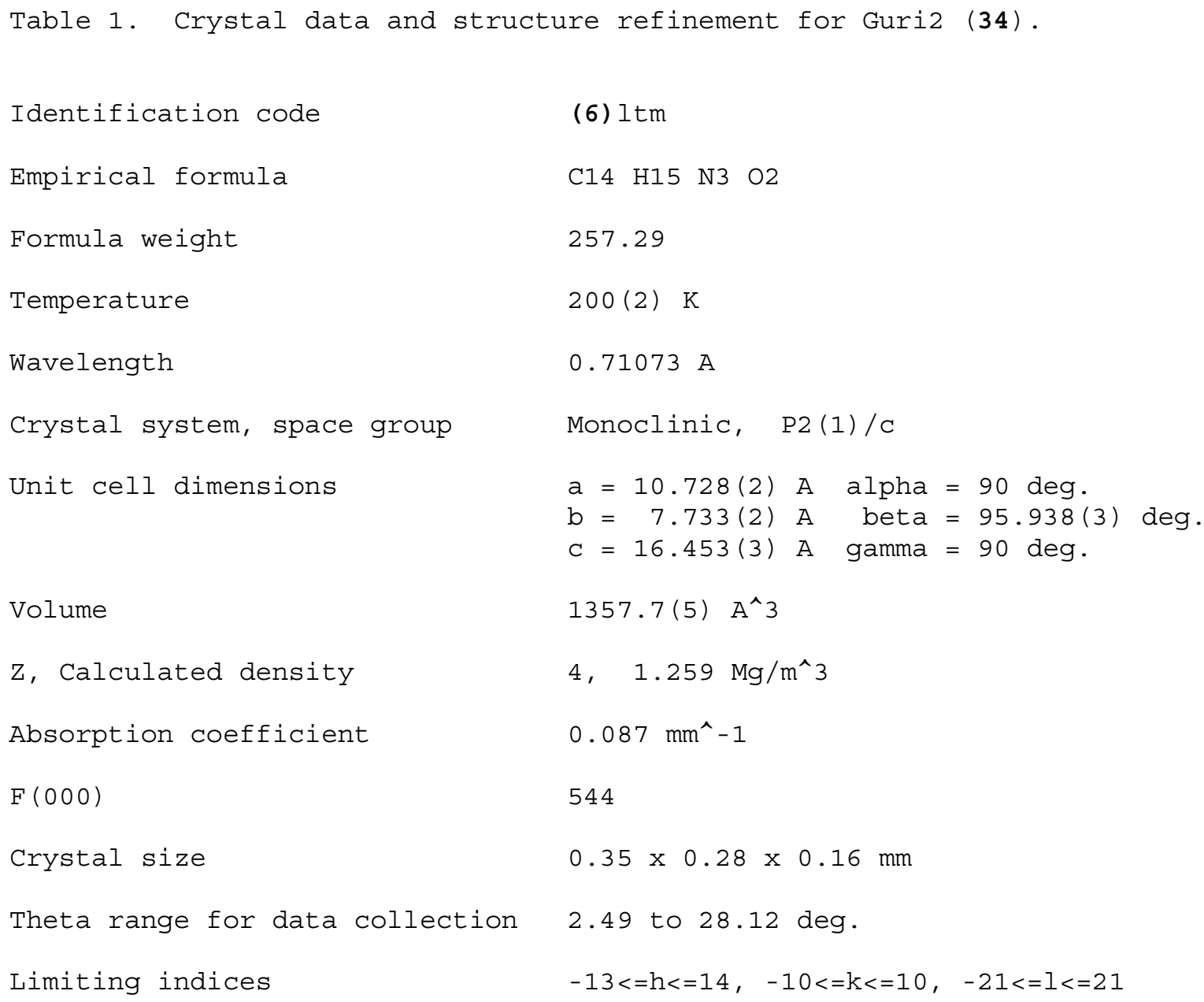




\begin{tabular}{|c|c|}
\hline Reflections collected / unique & $15034 / 3236[R($ int $)=0.0261]$ \\
\hline Completeness to theta $=28.12$ & $97.7 \%$ \\
\hline Absorption correction & None \\
\hline Max. and min. transmission & 0.9861 and 0.9701 \\
\hline Refinement method & Full-matrix least-squares on $F^{\wedge} 2$ \\
\hline Data / restraints / parameters & $3236 / 0 / 244$ \\
\hline Goodness-of-fit on $F^{\wedge} 2$ & 1.045 \\
\hline Final $R$ indices [I>2sigma(I)] & $\mathrm{R} 1=0.0452, \mathrm{wR} 2=0.1146$ \\
\hline $\mathrm{R}$ indices (all data) & $\mathrm{R} 1=0.0530, \mathrm{wR} 2=0.1197$ \\
\hline Largest diff. peak and hole & 0.346 and -0.215 e. $A^{\wedge}-3$ \\
\hline
\end{tabular}


Table 2. Atomic coordinates $\left(\mathrm{x}_{\left.10^{\wedge} 4\right)}\right)$ and equivalent isotropic displacement parameters $\left(\mathrm{A}^{\wedge} 2 \times 10^{\wedge} 3\right)$ for Guri2 (34).

$\mathrm{U}(\mathrm{eq})$ is defined as one third of the trace of the orthogonalized Uij tensor.

\begin{tabular}{lrrrr}
\hline & & & & \\
& $\mathrm{X}$ & $\mathrm{Z}$ & $\mathrm{U}(\mathrm{eq})$ \\
\hline $\mathrm{O}(1)$ & $6597(1)$ & $4925(1)$ & $9953(1)$ & $30(1)$ \\
$\mathrm{O}(2)$ & $6589(1)$ & $421(1)$ & $9585(1)$ & $34(1)$ \\
$\mathrm{N}(1)$ & $9124(1)$ & $2432(1)$ & $9326(1)$ & $29(1)$ \\
$\mathrm{N}(2)$ & $8644(1)$ & $3553(1)$ & $10601(1)$ & $30(1)$ \\
$\mathrm{N}(3)$ & $5092(1)$ & $2241(2)$ & $9926(1)$ & $34(1)$ \\
$\mathrm{C}(1)$ & $8366(1)$ & $3117(2)$ & $9820(1)$ & $25(1)$ \\
$\mathrm{C}(2)$ & $10304(1)$ & $2131(2)$ & $9653(1)$ & $32(1)$ \\
$\mathrm{C}(3)$ & $10673(1)$ & $2492(2)$ & $10464(1)$ & $36(1)$ \\
$\mathrm{C}(4)$ & $9817(1)$ & $3222(2)$ & $10931(1)$ & $35(1)$ \\
$\mathrm{C}(5)$ & $6995(1)$ & $3494(2)$ & $9506(1)$ & $25(1)$ \\
$\mathrm{C}(6)$ & $6199(1)$ & $1886(2)$ & $9681(1)$ & $25(1)$ \\
$\mathrm{C}(7)$ & $6788(1)$ & $3907(2)$ & $8594(1)$ & $30(1)$ \\
$\mathrm{C}(8)$ & $6382(1)$ & $5537(2)$ & $8335(1)$ & $40(1)$ \\
$\mathrm{C}(9)$ & $6170(2)$ & $5905(3)$ & $7503(1)$ & $55(1)$ \\
$\mathrm{C}(10)$ & $6365(2)$ & $4661(3)$ & $6939(1)$ & $58(1)$ \\
$\mathrm{C}(11)$ & $6764(2)$ & $3039(3)$ & $7192(1)$ & $54(1)$ \\
$\mathrm{C}(12)$ & $6977(1)$ & $2650(2)$ & $8018(1)$ & $40(1)$ \\
$\mathrm{C}(13)$ & $11190(2)$ & $1435(2)$ & $9095(1)$ & $44(1)$ \\
$\mathrm{C}(14)$ & $10136(2)$ & $3703(3)$ & $11809(1)$ & $52(1)$ \\
& & & & \\
\hline
\end{tabular}


Table 3. Bond lengths [A] and angles [deg] for (34).

\begin{tabular}{|c|c|}
\hline $\mathrm{O}(1)-\mathrm{C}(5)$ & $1.4186(14)$ \\
\hline $\mathrm{O}(2)-\mathrm{C}(6)$ & $1.2236(15)$ \\
\hline $\mathrm{N}(1)-\mathrm{C}(1)$ & $1.3186(16)$ \\
\hline$N(1)-C(2)$ & $1.3445(16)$ \\
\hline $\mathrm{N}(2)-\mathrm{C}(1)$ & $1.3331(16)$ \\
\hline$N(2)-C(4)$ & $1.3430(17)$ \\
\hline$N(3)-C(6)$ & $1.3213(17)$ \\
\hline$C(1)-C(5)$ & $1.5350(16)$ \\
\hline$C(2)-C(3)$ & $1.381(2)$ \\
\hline$C(2)-C(13)$ & $1.489(2)$ \\
\hline$C(3)-C(4)$ & $1.377(2)$ \\
\hline$C(4)-C(14)$ & $1.497(2)$ \\
\hline$C(5)-C(7)$ & $1.5270(16)$ \\
\hline$C(5)-C(6)$ & $1.5524(17)$ \\
\hline$C(7)-C(12)$ & $1.387(2)$ \\
\hline$C(7)-C(8)$ & $1.387(2)$ \\
\hline$C(8)-C(9)$ & $1.394(2)$ \\
\hline$C(9)-C(10)$ & $1.367(3)$ \\
\hline$C(10)-C(11)$ & $1.376(3)$ \\
\hline$C(11)-C(12)$ & $1.388(2)$ \\
\hline $\mathrm{C}(1)-\mathrm{N}(1)-\mathrm{C}(2)$ & $115.99(11)$ \\
\hline $\mathrm{C}(1)-\mathrm{N}(2)-\mathrm{C}(4)$ & $116.65(11)$ \\
\hline $\mathrm{N}(1)-\mathrm{C}(1)-\mathrm{N}(2)$ & $127.26(11)$ \\
\hline$N(1)-C(1)-C(5)$ & $119.97(10)$ \\
\hline$N(2)-C(1)-C(5)$ & $112.77(10)$ \\
\hline$N(1)-C(2)-C(3)$ & $121.03(12)$ \\
\hline$N(1)-C(2)-C(13)$ & $116.79(12)$ \\
\hline$C(3)-C(2)-C(13)$ & $122.16(12)$ \\
\hline$C(4)-C(3)-C(2)$ & $118.80(12)$ \\
\hline $\mathrm{N}(2)-\mathrm{C}(4)-\mathrm{C}(3)$ & $120.22(12)$ \\
\hline$N(2)-C(4)-C(14)$ & $116.98(13)$ \\
\hline$C(3)-C(4)-C(14)$ & $122.80(13)$ \\
\hline$O(1)-C(5)-C(7)$ & $108.99(10)$ \\
\hline $\mathrm{O}(1)-\mathrm{C}(5)-\mathrm{C}(1)$ & $107.67(9)$ \\
\hline$C(7)-C(5)-C(1)$ & $114.00(9)$ \\
\hline$O(1)-C(5)-C(6)$ & $109.11(9)$ \\
\hline$C(7)-C(5)-C(6)$ & $108.82(9)$ \\
\hline$C(1)-C(5)-C(6)$ & $108.15(9)$ \\
\hline $\mathrm{O}(2)-\mathrm{C}(6)-\mathrm{N}(3)$ & $124.16(12)$ \\
\hline $\mathrm{O}(2)-\mathrm{C}(6)-\mathrm{C}(5)$ & $121.03(11)$ \\
\hline$N(3)-C(6)-C(5)$ & $114.81(11)$ \\
\hline$C(12)-C(7)-C(8)$ & $119.35(13)$ \\
\hline$C(12)-C(7)-C(5)$ & $120.55(12)$ \\
\hline$C(8)-C(7)-C(5)$ & $120.08(12)$ \\
\hline$C(7)-C(8)-C(9)$ & $120.13(16)$ \\
\hline$C(10)-C(9)-C(8)$ & $120.13(17)$ \\
\hline$C(9)-C(10)-C(11)$ & $120.04(15)$ \\
\hline$C(10)-C(11)-C(12)$ & $120.57(18)$ \\
\hline$C(7)-C(12)-C(11)$ & $119.77(16)$ \\
\hline
\end{tabular}

Symmetry transformations used to generate equivalent atoms:

Table 4. Anisotropic displacement parameters $\left(A^{\wedge} 2 \times 10^{\wedge} 3\right.$ ) for (34). The anisotropic displacement factor exponent takes the form: $-2 \mathrm{pi}^{\wedge} 2\left[\mathrm{~h}^{\wedge} 2 \mathrm{a}{ }^{\wedge} 2 \mathrm{U} 11+\ldots+2 \mathrm{hk} \mathrm{a}^{*} \mathrm{~b} * \mathrm{U} 12\right.$ ] 


\begin{tabular}{|c|c|c|c|c|c|c|}
\hline & U11 & $\mathrm{U} 22$ & U33 & U2 3 & U13 & U12 \\
\hline$O(1)$ & $29(1)$ & $28(1)$ & $33(1)$ & $-3(1)$ & $2(1)$ & $3(1)$ \\
\hline$O(2)$ & $28(1)$ & $28(1)$ & $47(1)$ & $-1(1)$ & $8(1)$ & $2(1)$ \\
\hline $\mathrm{N}(1)$ & $25(1)$ & $31(1)$ & $30(1)$ & $1(1)$ & $1(1)$ & $2(1)$ \\
\hline $\mathrm{N}(2)$ & $29(1)$ & $36(1)$ & $26(1)$ & $2(1)$ & $1(1)$ & $-4(1)$ \\
\hline $\mathrm{N}(3)$ & $27(1)$ & $25(1)$ & $51(1)$ & $0(1)$ & $12(1)$ & $0(1)$ \\
\hline$C(1)$ & $23(1)$ & $25(1)$ & $26(1)$ & $4(1)$ & $0(1)$ & $-1(1)$ \\
\hline$C(2)$ & $26(1)$ & $33(1)$ & $36(1)$ & $6(1)$ & $2(1)$ & $0(1)$ \\
\hline$C(3)$ & $24(1)$ & $47(1)$ & $36(1)$ & $10(1)$ & $-3(1)$ & $-3(1)$ \\
\hline$C(4)$ & $30(1)$ & $45(1)$ & $29(1)$ & $7(1)$ & $-3(1)$ & $-7(1)$ \\
\hline$C(5)$ & $23(1)$ & $26(1)$ & $25(1)$ & $1(1)$ & $2(1)$ & $2(1)$ \\
\hline$C(6)$ & $24(1)$ & $29(1)$ & $23(1)$ & $1(1)$ & $-1(1)$ & $1(1)$ \\
\hline$C(7)$ & $19(1)$ & $43(1)$ & $28(1)$ & $6(1)$ & $1(1)$ & $-1(1)$ \\
\hline$C(8)$ & $31(1)$ & $52(1)$ & $39(1)$ & $15(1)$ & $5(1)$ & $7(1)$ \\
\hline$C(9)$ & $39(1)$ & $80(1)$ & $47(1)$ & $32(1)$ & $3(1)$ & $8(1)$ \\
\hline$C(10)$ & $36(1)$ & $107(2)$ & $30(1)$ & $22(1)$ & $-1(1)$ & $-3(1)$ \\
\hline$C(11)$ & $40(1)$ & $93(1)$ & $29(1)$ & $-6(1)$ & $4(1)$ & $-6(1)$ \\
\hline$C(12)$ & $33(1)$ & $57(1)$ & $30(1)$ & $-3(1)$ & $1(1)$ & $0(1)$ \\
\hline$C(13)$ & $30(1)$ & $57(1)$ & $44(1)$ & $3(1)$ & $4(1)$ & $12(1)$ \\
\hline$C(14)$ & $40(1)$ & $85(1)$ & $29(1)$ & $0(1)$ & $-6(1)$ & $-8(1)$ \\
\hline
\end{tabular}

